\title{
Waste Fiber-Based Poly(hydroxamic acid) Ligand for Toxic Metals Removal from Industrial Wastewater ${ }^{\dagger}$
}

\author{
Md. Lutfor Rahman ${ }^{1,2, * \mathbb{D}}$, Zhi-Jian Wong ${ }^{1}$, Mohd Sani Sarjadi ${ }^{1}\left(\mathbb{D}\right.$, Collin G. Joseph $^{1}$ (D) Sazmal E. Arshad ${ }^{1}(\mathbb{D}$, \\ Baba Musta ${ }^{1}$ and Mohd Harun Abdullah ${ }^{1}$
}

1 Faculty of Science and Natural Resources, Universiti Sabah Malaysia, Kota Kinabalu 88400, Malaysia; javentwong@gmail.com (Z.-J.W.); msani@ums.edu.my (M.S.S.); collin@ums.edu.my (C.G.J.); sazmal@ums.edu.my (S.E.A.); babamus@ums.edu.my (B.M.); harunabd@ums.edu.my (M.H.A.)

2 Seaweed Research Unit, Faculty of Science and Natural Resources, Universiti Malaysia Sabah, Kota Kinabalu 88400, Malaysia

* Correspondence: lotfor@ums.edu.my

$+\quad$ This paper is an extended version of paper published in The First International Conference on "Green" Polymer Materials 2020, 5-25 November 2020.

Citation: Rahman, M.L.; Wong, Z.-J.; Sarjadi, M.S.; Joseph, C.G.; Arshad, S.E.; Musta, B.; Abdullah, M.H. Waste Fiber-Based Poly(hydroxamic acid) Ligand for Toxic Metals Removal from Industrial Wastewater. Polymers 2021, 13, 1486. https://doi.org/ $10.3390 /$ polym 13091486

Academic Editor: Antonio Pizzi

Received: 18 March 2021

Accepted: 21 April 2021

Published: 6 May 2021

Publisher's Note: MDPI stays neutral with regard to jurisdictional claims in published maps and institutional affiliations.

Copyright: (c) 2021 by the authors. Licensee MDPI, Basel, Switzerland. This article is an open access article distributed under the terms and conditions of the Creative Commons Attribution (CC BY) license (https:// creativecommons.org/licenses/by/ $4.0 /)$

\begin{abstract}
Toxic metals in the industrial wastewaters have been liable for drastic pollution hence a powerful and economical treatment technology is needed for water purification. For this reason, some pure cellulosic materials were derived from waste fiber to obtain an economical adsorbent for wastewater treatment. Conversion of cellulose into grafting materials such as poly(methyl acrylate)-grafted cellulose was performed by free radical grafting process. Consequently, poly(hydroxamic acid) ligand was produced from the grafted cellulose. The intermediate products and poly(hydroxamic acid) ligand were analyzed by FT-IR, FE-SEM, TEM, EDX, and XPS spectroscopy. The adsorption capacity $\left(q_{e}\right)$ of some toxic metals ions by the polymer ligand was found to be excellent, e.g., copper capacity $\left(q_{e}\right)$ was $346.7 \mathrm{mg} \cdot \mathrm{g}^{-1}$ at $\mathrm{pH}$ 6. On the other hand, several metal ions such as cobalt chromium and nickel also demonstrated noteworthy sorption capacity at $\mathrm{pH}$ 6. The adsorption mechanism obeyed the pseudo second-order rate kinetic model due to the satisfactory correlated experimental sorption values $\left(q_{e}\right)$. Langmuir model isotherm study showed the significant correlation coefficient with all metal ions $\left(R^{2}>0.99\right)$, indicating that the single or monolayer adsorption was the dominant mode on the surface of the adsorbent. This polymer ligand showed good properties on reusability. The result shows that the adsorbent may be recycled for 6 cycles without any dropping of starting sorption capabilities. This polymeric ligand showed outstanding toxic metals removal magnitude, up to $90-99 \%$ of toxic metal ions can be removed from industrial wastewater.
\end{abstract}

Keywords: adsorption; waste fiber; poly(hydroxamic acid); wastewater; heavy metals

\section{Introduction}

In the current era of globalization, the earth is confronted by abundant obstructive incident and challenges due to the anthropogenic activities for economic reasons. As a result, our planet is facing a diverse environmental problem, such as water pollution, intolerable solid waste generation, climate change, or global warming, resulting in significant environmental deterioration [1,2]. The effect of the environmental issues is horrifying on a global economic and social development scale. Heavy metals, one of the worst industrial pollutant, have been released at a large amount into the environment over the last few decades, and these heavy metals are not biodegradable [3]. Various types of industrial operation, e.g., electroplating, electrolysis depositions, milling, and metal coatings, etc., generated the harmful non-biodegradable toxic heavy metals in the factory sewage/wastewater [4]. Thus, adsorption investigators are given a wide attention and have made critical responses with different remediation techniques to address the issue of heavy-metals-contaminated residual discharges. Many countries have enacted strict regulations, environmental acts, and 
actions in view of this problem, resulting in a widespread practice of compelling industries to treat their heavy metals discharge before releasing it into the ecosystem [3]. The EPA in alliance with the WHO has set down the most reasonable level of toxic metals allowed in the environment to control the level and discharge of toxic metals in order to address the ecological, biological, and industrial concerns from industrial effluents. Adsorption, a phase transfer process, is a simple and effective process for wastewater treatment due to its simplistic nature of the adsorption process, which is easy to conduct with a low investment, and suitability to treat wastewater contains trace amount of heavy metals [5-10]. However, many adsorbents suffer from low adsorption capacity, selectivity issue, and difficulty to be regenerated making it an unsuitable choice for treatment process. Therefore, magnitude of interest has grown in the development of new adsorbent materials [11].

Absolutely, water is essential substance for all living elements, therefore, water has a vital role to the environment for the existence of life. However, water quality has been affected due to the urbanization, industrialization, agricultural activities, etc. Many types of water pollution and existence of toxic metals in the various types of water causes detrimental effects to the safe water [12-15]. An effective treatment method is needed for safe water to avoid the detrimental health effects caused by the toxic heavy metals. Physical treatment methods such as adsorption [16], precipitation [17], coagulation [18], reverse osmosis [19], and membrane filtration [20] have been conventionally used in industry processes. The adsorption by bio-adsorbents is also been validated as a promising and cost-effective method among other methods to get safe water [21]. Chemically modified cellulose can be a potential bio-adsorbent, consequently, chemical conversion of the cellulose might intensify its sorption performance as an efficient adsorbent [22].

The free radical polymerization method has been widely used to produce the grafting copolymers from various cellulose materials. Variety of the methods have been utilized to produce free radicals for polymerization reactions. However, ceric ions from ceric ammonium nitrate (CAN) can be a simple method to produce initiator radicals for grafting copolymerization. Certainly, the radicals are created on the cellulose (AGU, anhydroglucose unit) resulting in the formation of covalent bonds with the desired monomers; further, in many propagating units, the chains grow until termination process occurs. Ultimately, a grafting copolymer product can be generated via disproportionation step or combination of two growing chains of cellulose molecules [23-25]. Eventually, there is chemical conversion of the grafted cellulose into the chelating ligands specially hydroxamic acid for the coordination with metals ions in a simple binding system. In principle, atoms, molecules, or small groups of atoms exhibiting negatively or neutral charge, which may connect to a central metal atom, eventually form a coordination compound [26-28].

In this study, cellulose is extracted from waste fiber by alkaline solution for delignification. Then, the cellulose was used in grafting reaction with monomer to produce the poly(methyl acrylate)-grafted cellulose. Grafted cellulose was then transformed into the poly(hydroxamic acid) ligand for the sorption of toxic metals from synthetic water as well as electroplating wastewater. The spectroscopy analyses were used to perform the morphological and structural investigation of the intermediate and final products. Eventually, the adsorption capacity of poly(hydroxamic acid) ligand was evaluated using various parameter such as $\mathrm{pH}$ values, contact times, and isothermal study including the reusability study.

\section{Materials and Methods}

\subsection{Extraction of Cellulose}

Waste pandanus fruit fibers were obtained from Melinsung summer bay in Papar, Sabah, Malaysia. On the other hand, durian rinds were obtained from a random fruit market in Kota Kinabalu, Sabah. Waste pandanus fruit fiber and durian rinds were cut into small pieces and were ground. About $200 \mathrm{~g}$ of mixed waste fiber was boiled with $800 \mathrm{~mL}$ of sodium hydroxide (Merck, Germany) solution (18\%) for $5 \mathrm{~h}$. The fibers were washed with water and then boiled with approximately $550 \mathrm{~mL}$ of glacial acetic acid (Merck, Germany) 
for an hour followed by washing with water. After that, $400 \mathrm{~mL}$ of hydrogen peroxide (bleaching agent, Merck, Germany) was added into the cooking fibers followed by $400 \mathrm{~mL}$ of $\mathrm{NaOH}(8 \%)$, and it was boiled for $1 \mathrm{~h}$. The resulting cellulose was washed 5 times with water and dried in oven at $50{ }^{\circ} \mathrm{C}$. The dried cellulose was used in grafting process for modification of cellulose into grafting copolymer [29].

\subsection{Graft Copolymerization}

The copolymerization reaction was executed with a $1 \mathrm{~L}$ three-neck round-bottom flask immersed into thermostat water bath fixed with a stirrer and condenser. About $6.5 \mathrm{~g}$ of cellulose, $500 \mathrm{~mL}$ of distilled water, $1.1 \mathrm{~mL}$ of $\mathrm{H}_{2} \mathrm{SO}_{4}(50 \%), 1.1 \mathrm{~g}$ of ammonium ceric nitrate $\left(10 \mathrm{~mL} \mathrm{H}_{2} \mathrm{O}\right)$, and $10 \mathrm{~mL}$ of methyl acrylate (Merck, Germany) were heated at $55^{\circ} \mathrm{C}$ with stirring under $\mathrm{N}_{2}$ atmosphere, and the reaction was carried out according to previous work [30]. The work-up procedure was also accomplished by previous work [30]. The poly(methyl acrylate)-grafted cellulose product was dried in an oven under $50{ }^{\circ} \mathrm{C}$ for $24 \mathrm{~h}$.

\subsection{Synthesis of Poly(hydroxamic acid) Ligand}

Hydroxylamine (Merck, Germany) solution $(300 \mathrm{~mL})$ was made ready for oximation reaction according to the previous work [31]. About $10.0 \mathrm{~g}$ of poly(methyl acrylate)-grafted cellulose was added into a round-bottom flask with freshly prepared hydroxylamine solution at $\mathrm{pH} 10$. The mixture was heated at $70^{\circ} \mathrm{C}$ with stirring for $6 \mathrm{~h}$. The work-up procedure was accomplished by previous work $[23,25]$. The resulting poly(hydroxamic acid) ligand was dried at $50^{\circ} \mathrm{C}$ for $24 \mathrm{~h}$.

\subsection{Batch Adsorption Studies}

A series of batch adsorption experiment was used to ascertain the metal ion binding capacity with various $\mathrm{pH}$ from 3 to 6 according to previous work $[17,24]$. Typically, $100 \mathrm{mg}$ of poly(hydroxamic acid), $5 \mathrm{~mL}$ of distilled water, and $10 \mathrm{~mL}$ of $0.1 \mathrm{M}^{\text {of } \mathrm{CH}_{3} \mathrm{COONa}}$ (Merck, Germany) buffer (pH 3 to 6) were placed into plastic bottles. Exactly $5 \mathrm{~mL}$ of $0.1 \mathrm{M}$ of metal ions (copper sulfate- $5 \mathrm{H}_{2} \mathrm{O}$, cobalt chloride, chromium chloride, and nickel sulphate, all obtained from Merck, Germany)) was added into plastic bottles and stirred for $2 \mathrm{~h}$. After the adsorption reached equilibrium, the metal cation concentration was analyzed by ICP-OES (Perkin Elmer OPTIMA 7300, Winter Street Waltham, MA 02451, USA). The metal ions concentration can be estimated by the following Equation (1):

$$
q_{e}=\frac{\left(C_{o}-C_{e}\right) V}{L}
$$

where $q_{e}$ stands for adsorption capacity $\left(\mathrm{mg} \cdot \mathrm{g}^{-1}\right) . C_{o}$ and $C_{e}$ are the initial and equilibrium concentration of metal ions $\left(\mathrm{mg} \cdot \mathrm{L}^{-1}\right)$, respectively. $V$ is the volume of the metal ions solution $(\mathrm{mL})$, and $L$ is the mass of polymeric ligand $(\mathrm{g})$.

The isothermal study was performed according to the previous work [31-34]. Similar batch adsorption process was carried out using the $100 \mathrm{mg}$ of adsorbent, $10 \mathrm{~mL}$ of distilled water, and $5 \mathrm{~mL}$ of $0.1 \mathrm{M}$ of $\mathrm{CH}_{3} \mathrm{COONa}$ buffer at $\mathrm{pH}$, and exactly $5 \mathrm{~mL}$ of different concentrations of metal ions solution (10-2400 ppm) was shaken for $2 \mathrm{~h}$. After equilibrium adsorption, the metal action concentration is analyzed by ICP-OES according to Equation (1).

The kinetic adsorption studies were also performed according to the previous work [35-37], batch adsorption was performed using the $100 \mathrm{mg}$ of adsorbent, $5 \mathrm{~mL}$ of distilled water, $10 \mathrm{~mL}$ of $0.1 \mathrm{M}$ of $\mathrm{CH}_{3} \mathrm{COONa}$ buffer solution at $\mathrm{pH}$, and exactly $5 \mathrm{~mL}$ of $0.1 \mathrm{M}$ of metal ion solution. The mixture was stirred using shaker machine at time intervals of 5, 15, 30, 60, and $120 \mathrm{~min}$. Then, concentrations of metal cation were determined by ICP-OES, and calculation was performed using Equation (2):

$$
q_{t}=\frac{\left(C_{o}-C_{t}\right) V}{L}
$$


where $q_{t}$ is the quantity of metal ions adsorbed at time $t\left(\mathrm{mg} \cdot \mathrm{g}^{-1}\right)$. Other parameters are expressed in Equation (1).

\subsection{Desorption and Reusability Studies}

For a typical desorption study, all metal ions were held at the adsorbent as a metal complexes. The metal ions were removed from the ligand using $2 \mathrm{M}$ of $\mathrm{HCl}$ solution. The ligand was regenerated back by washing with water until remaining $\mathrm{HCl}$ was removed from the ligand. Then, $\mathrm{CH}_{3} \mathrm{COONa}$ buffer of $\mathrm{pH} 6$ was added with every cycle of adsorption experiment for the reusability test for six cycles of adsorption-desorption process [25].

\section{Results and Discussion}

\subsection{Synthesis of Poly(hydroxamic acid) Ligand}

In this study, a monomer, namely, methyl acrylate was used in the grafting reaction onto cellulose at optimum conditions. According to the methods reported on the graft copolymer reaction, the mixture of cellulose, monomer, and an initiator in a round-bottom flask was constantly agitated and purged with nitrogen gas to create an inert condition in order to get rid of oxygen gas during graft copolymerization reaction $[22,25]$. The cellulosegrafted copolymer was then converted into chelating ligand, namely, poly(hydroxamic acid), and it was used as the adsorbents in the batch adsorption studies. The copolymerization reaction, depicted in Scheme 1, resulted to the poly(methyl acrylate)-grafted cellulose and further oximation reaction gave the poly(hydroxamic acid) ligand (Scheme 1).

As expected, poly(hydroxamic acid) ligand was derived white in color (navajo white) as referred to previous studied $[23,25]$. The chelating ligand was prepared by the oximation reaction of acrylate functional groups containing esters of the poly(methyl acrylate)-grafted cellulose in basic condition. The reaction was performed in optimum conditions, whereby the mixture was constantly agitated under $\mathrm{pH} 10$ for $4 \mathrm{~h}$ [25]. In this reaction, $10.00 \mathrm{~g}$ of cellulose-grafted copolymer yielded $12.11 \mathrm{~g}$ of poly(hydroxamic acid) ligand. During adsorption process, poly(hydroxamic acid) ligand bonded with $\mathrm{Cu}^{2+}$ ions to form poly(hydroxamic acid)-Cu complex by coordination system. Other metals-ligand complexes occurred by the same chelating ligand. The image of the poly(hydroxamic acid)metal complexes formed by the coordination with copper, cobalt, chromium, and nickel is displayed in Figure 1, in which navajo white color of ligand turned into respective metal ions colors.

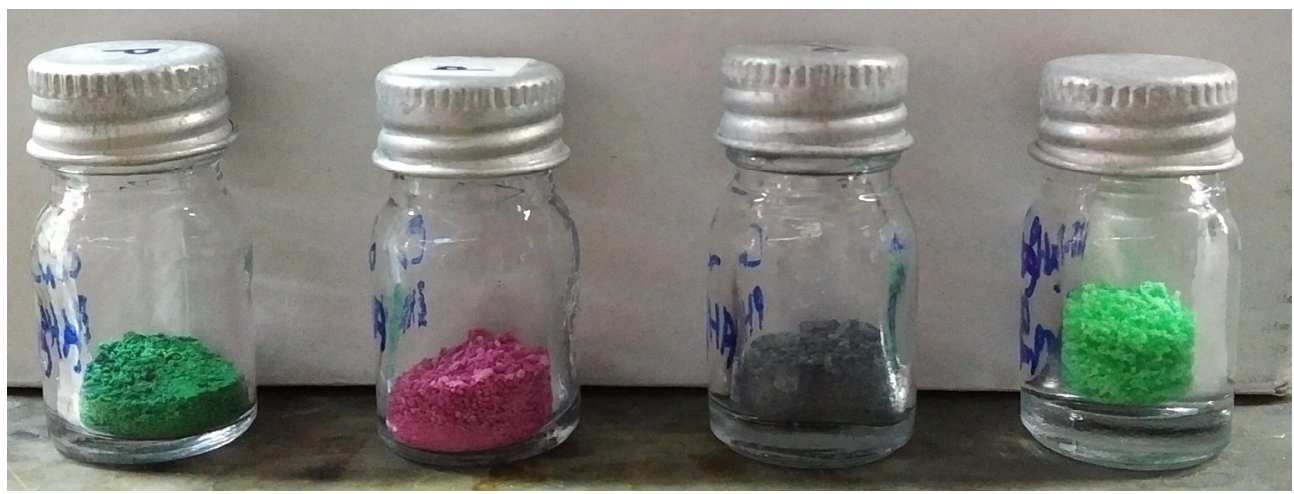

Figure 1. Poly(hydroxamic acid) with metal complex as the ligand-Cu (left), ligand-Co (second left), ligand-Cr (third from left), and ligand-Ni (utmost right). 

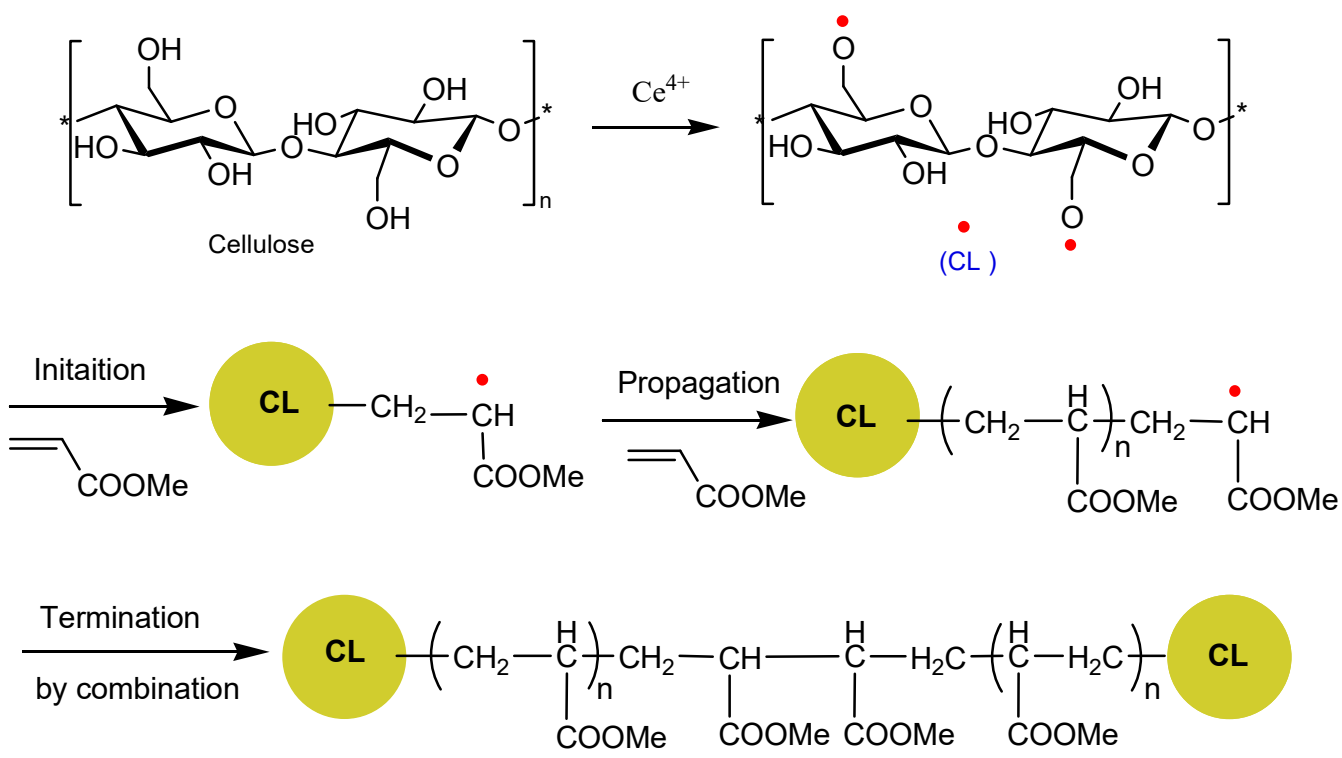

Poly(methyl acrylate)-grafted cellulose
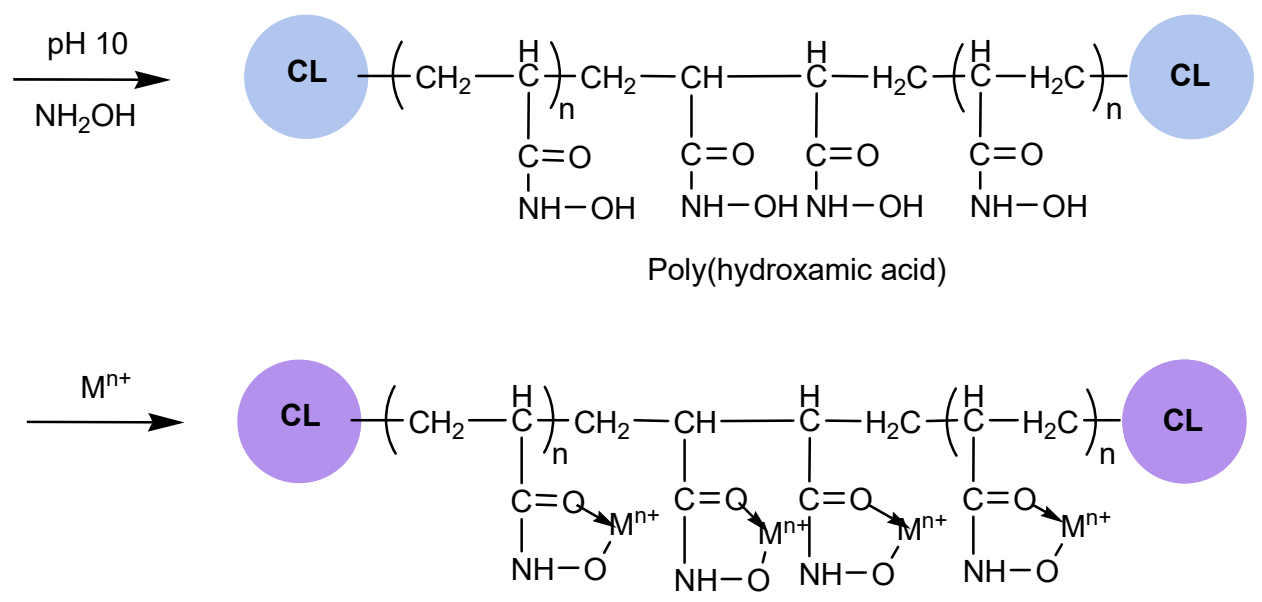

Poly(hydroxamic acid)-metal complex

Scheme 1. Poly(methyl acrylate)-grafted cellulose and poly(hydroxamic acid)-metal complex (CL indicated an anhydroglucose unit).

\subsection{FT-IR Analysis}

FT-IR spectra of waste cellulose, grafting copolymer, and poly(hydroxamic acid) are shown in Figure 2 (Perkin Elmer Spectrum 100, Winter Street, Waltham, MA, USA). FTIR spectra obtained for a cellulosic material is shown in Figure 2a. A traceable peak at $886 \mathrm{~cm}^{-1}$ proved the $\mathrm{C}_{1}-\mathrm{H}$ deformation of glycosidic linkage [38]. A significant vibration for the of C-O-C pyranose ring showed stretching at $1152 \mathrm{~cm}^{-1}$. The stretching of $\mathrm{C}-\mathrm{H}$ band appeared typically at $2907 \mathrm{~cm}^{-1}$, and an oblivious O-H stretching band was present at $3371 \mathrm{~cm}^{-1}$ as the cellulose structure contains six $\mathrm{OH}$ groups in each repeating unit. Besides, there were another two peaks shown at 1624 and $1408 \mathrm{~cm}^{-1}$, representing the bending modes of absorbed water and $\mathrm{CH}_{2}$ bonds, respectively.

IR spectra of the cellulose-graft-poly(methyl acrylate) are represented by the redcolored line in Figure $2 \mathrm{~b}$. A new prominent peak at $1715 \mathrm{~cm}^{-1}$, associated with the $\mathrm{C}=\mathrm{O}$ stretching band was found as the grafted copolymer contains COOMe. There are two notable peaks rendered to the $\mathrm{C}-\mathrm{H}$ bending scissoring by virtue of $\mathrm{CH}_{2}$ and wagging due to $\mathrm{CH}_{2}$ at 1452 and $822 \mathrm{~cm}^{-1}$, respectively $[23,25]$. In spite of the expected peak exhibited in the copolymer product, other peaks conserved for cellulose structure [25]. 


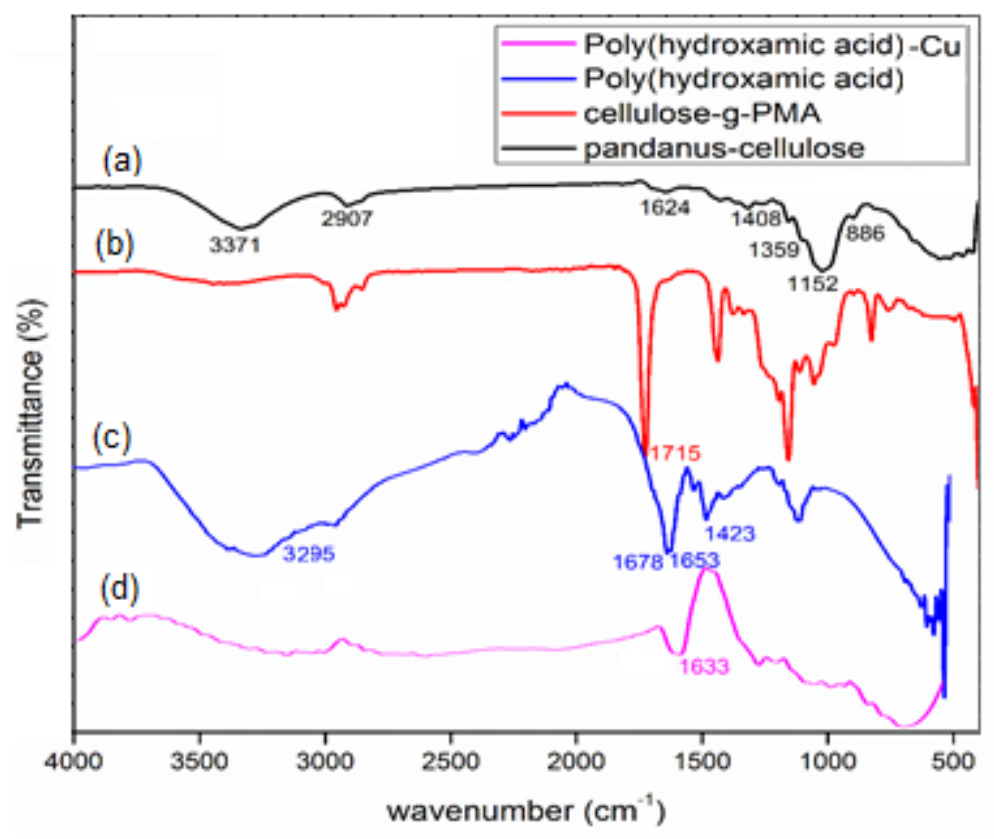

Figure 2. FT-IR spectra of (a) waste cellulose, (b) poly(methyl acrylate)-grafted cellulose (c) poly(hydroxamic acid), and (d) poly(hydroxamic acid)-copper complex.

The blue-colored spectrum is representing the poly(hydroxamic acid) ligand (Figure 2c). A widen peak was detected at $3295 \mathrm{~cm}^{-1}$, which designated the existence of stretching band for $\mathrm{N}-\mathrm{H}$ bonding belonging to the hydroxamic acid functional group. Consequently, as previously seen in Figure $2 \mathrm{~b}$, a widen peak for $\mathrm{C}=\mathrm{O}$ stretching of the grafted copolymers at $1715 \mathrm{~cm}^{-1}$ was disappeared. Subsequently, loss of $\mathrm{C}=\mathrm{O}$ stretching generated our anticipated bands at 1678 and $1653 \mathrm{~cm}^{-1}$, established for the hydroxamic acid functional groups, and both represented the $\mathrm{C}=\mathrm{O}$ stretching and $\mathrm{N}-\mathrm{H}$ bending, respectively. The spectra proved the successful conversion of the poly(hydroxamic acid) [23].

Eventually, the evidence of metal-ligand complexes is shown in Figure $2 \mathrm{~d}$ for the copper-ligand coordination event occurred during adsorption process. The $\mathrm{N}-\mathrm{H}$ band of the ligand $\left(3295 \mathrm{~cm}^{-1}\right)$ was changed by metal-ligand coordination system. Thus, the 1678 and $1653 \mathrm{~cm}^{-1}$ bands are associated with the stretching of $\mathrm{C}=\mathrm{N}$ and $\mathrm{N}-\mathrm{H}$ bonds respectively; both stretching bands are widen due to the formation of copper-ligand complexation, and this evidence is supported by the coordination of the copper ions by the polymer ligand [23].

\subsection{FE-SEM Analysis}

Characterization by the FE-SEM investigation was useful for some morphological analyses with JSM-7900F (JEOL, Tokyo, Japan). The SEM image of the pure cellulose extracted from waste fiber emerged as a smooth wooden stick-like structure as shown in Figure 3a. After the chemical modification of the cellulose into the grafting copolymer, the wooden stick-like structure was diminished, and unsmooth superficial morphology appeared for the grafted polymer in the SEM micrograph as shown in Figure 3b. No homopolymer lumps or distinguishable trace of material was found in the grafted copolymer. Further conversion of the grafted copolymer into the desired poly(hydroxamic acid) ligand changes morphological texture. As such, the unsmooth morphology of grafted copolymer disappeared, and unsmooth variable spherical beads were formed as shown in Figure 3c. Once polymer ligand complex was formed with the copper ions, then the spherical beads shrinker to form the smaller beads due to the coordination bonding that occurred between the ligand and copper ions (Figure 3d). The copper complex was also further analyzed by the TEM and EDX spectra. 

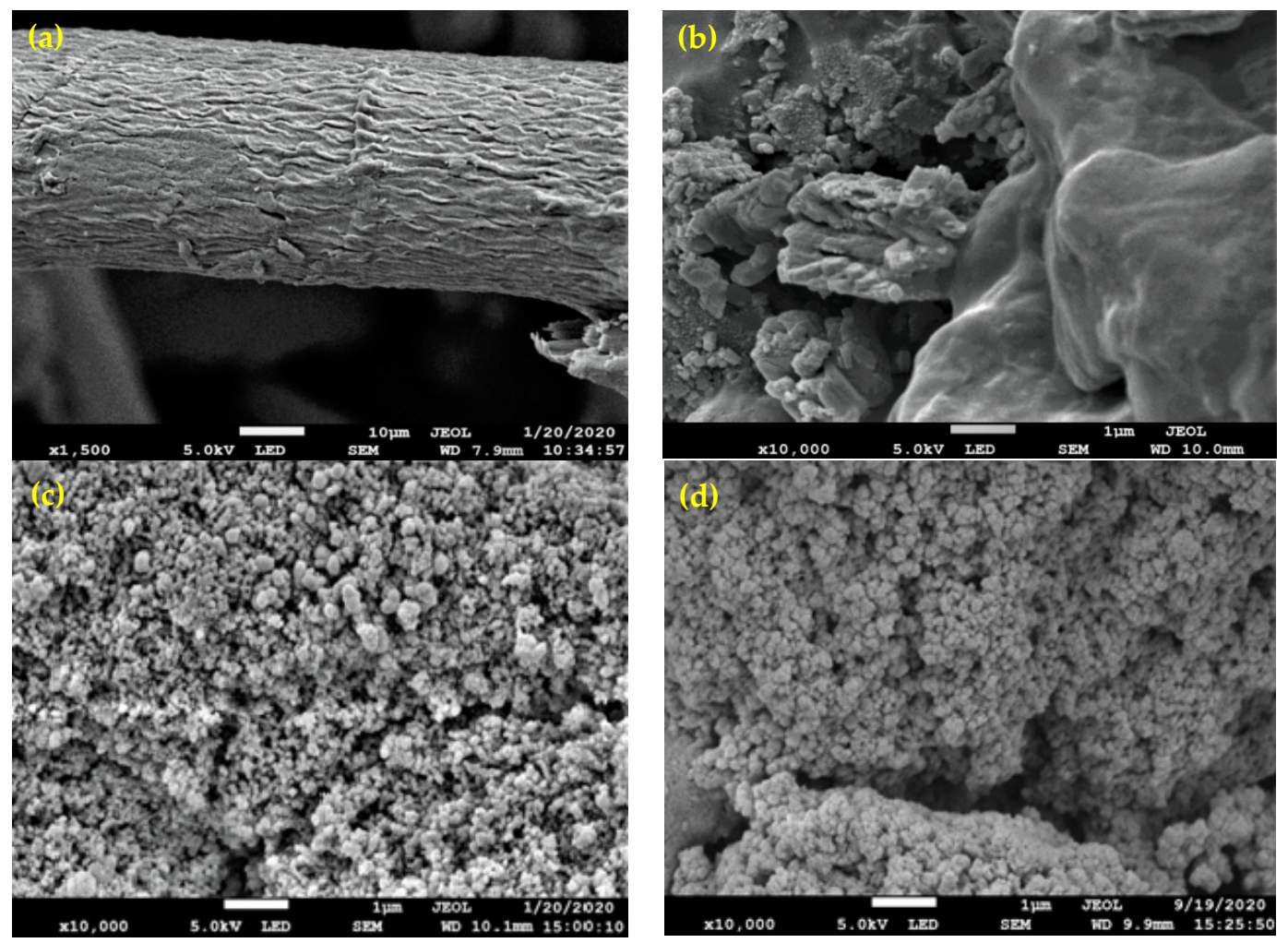

Figure 3. FE-SEM micrograph of (a) pure cellulose, (b) poly(methyl acrylate)-grafted cellulose, (c) poly(hydroxamic acid), and (d) poly(hydroxamic acid) ligand-copper complex.

\subsection{TEM and EDX Analysis}

Transmission electron microscope (TEM) examination was accomplished on Tecnai G2 Spirit BioTwin TEM (Dawson Creek Drive Hillsboro, USA) with a copper-grid-coated sample holder using $120 \mathrm{kV}$ energy. TEM examination displayed the existence of copper nano complex onto waste cellulose-based poly(hydroxamic acid) surface, and average size of copper complex was estimated to be about $\varnothing=21.7 \pm 2 \mathrm{~nm}$ (Figure 4a). The copper nanocomplex showed small spherical morphology, and an irregular spreading of copper species was spotted with variable sizes. Further examination of the poly(hydroxamic acid)-Cu(II) complex was carried out through energy-dispersive X-ray (EDX) tool (JEOL Tokyo, Japan) (Figure 4 b). Elements such as $\mathrm{C}, \mathrm{O}$, and $\mathrm{N}$ were mainly detected from the poly(hydroxamic acid, however, the presence of $35.4 \%$ of the copper species $(8.03 \mathrm{keV})$ was determined, which was incorporated into the poly(hydroxamic acid)-Cu(II) complex.
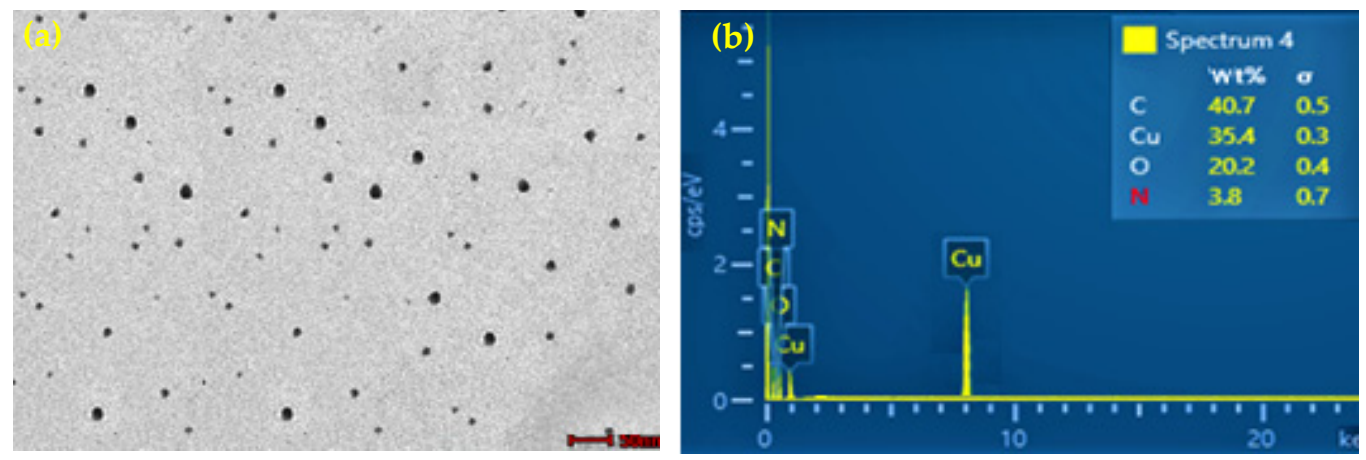

Figure 4. (a) TEM micrograph and (b) energy-dispersive X-ray (EDX) spectra of poly(hydroxamic acid)-Cu(II) complex. 


\subsection{X-ray Photoelectron Spectroscopy Analysis (XPS)}

The X-ray photoelectron spectroscopy (PHI Quantera II, Physical Electronics, Lake Drive East, Chanhassen, MN, USA) was performed on the poly(hydroxamic acid) ligand and ligand-copper complex as shown Figure 5. The bidentate ligand, i.e., hydroxamic acid, strongly bonded with copper species, therefore, the XPS analyses can be most effective tools to determine the binding properties of copper with ligand. The survey scan XPS of poly(hydroxamic acid) displayed the binding energies (BEs) peaks at 284.1, 398.1, and $531.2 \mathrm{eV}$ corresponding to $1 \mathrm{~s}$ of carbon, nitrogen, and oxygen, respectively (Figure 5a). Poly(hydroxamic acid) ligand bonded with copper ions and formed a five-member $\mathrm{Cu}$ (II) complex that produced new BEs peaks at 935.4, 955.5, 125.3, and $80.4 \mathrm{eV}$ corresponding to $\mathrm{Cu} 2 \mathrm{p} 3 / 2, \mathrm{Cu} 2 \mathrm{p} 1 / 2, \mathrm{Cu} 3 \mathrm{~s}$, and Cu3p3, respectively (Figure $5 \mathrm{~b}$ ). In addition, the peaks belonging to the $\mathrm{C} 1 \mathrm{~s}, \mathrm{~N} 1 \mathrm{~s}$, and $\mathrm{O} 1 \mathrm{~s}$ were emerged with increased BEs at 286.2, 402.5, and $534.5 \mathrm{eV}$, respectively, due to decrease in electron density at ligand site (Figure $5 \mathrm{~b}$ ).

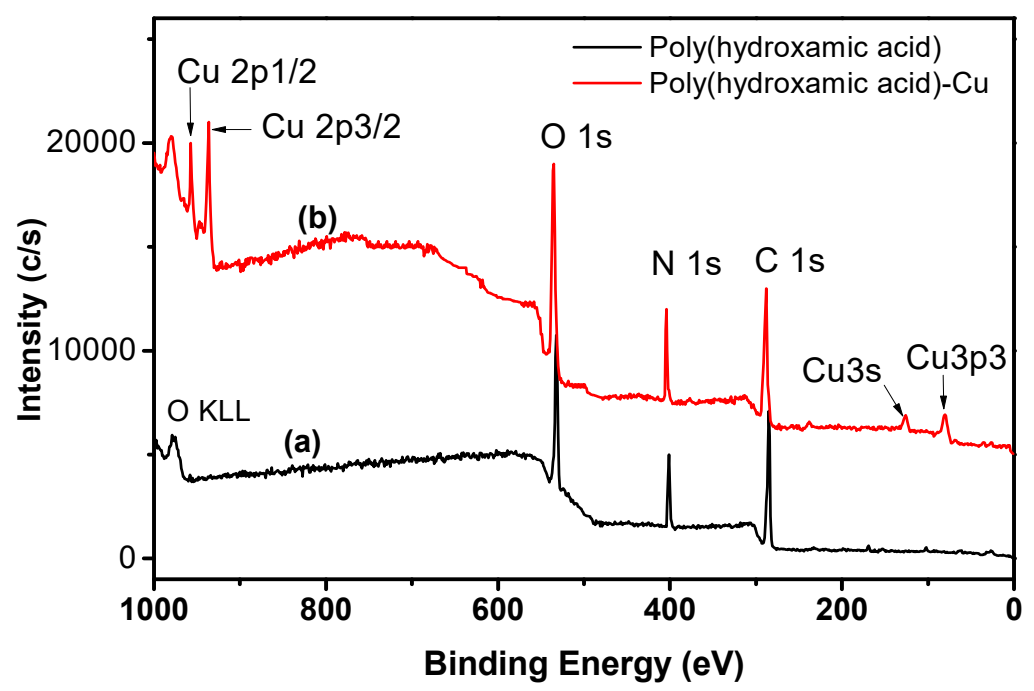

Figure 5. XPS spectra of (a) poly(hydroxamic acid) ligand and (b) poly(hydroxamic acid)-Cu(II).

The narrow scans of oxygen and nitrogen atoms were performed for the confirmation of copper complex with hydroxamic ligand. The XPS spectra of poly(hydroxamic acid) ligand showed two peaks at the BEs of 530.5 and $532.2 \mathrm{eV}$, which corresponds to the $\mathrm{O} 1 \mathrm{~s}$ in the $\mathrm{O}-\mathrm{NH}$ and $\mathrm{C}=\mathrm{O}$ groups, respectively (Figure $6 \mathrm{a}$ ). However, after complexation of ligand with copper ions, the BEs of $\mathrm{O} 1$ s for O-NH increased from 530.5 to $531.0 \mathrm{eV}$ and the $\mathrm{O} 1 \mathrm{~s}$ for $\mathrm{C}=\mathrm{O}$ was split into two peaks with increased BEs of 533.0 and $534.6 \mathrm{eV}$ (Figure 6b). The peak appearing at BEs of $533.0 \mathrm{eV}$ corresponds to $\mathrm{O} 1 \mathrm{~s}$ for $\mathrm{C}=\mathrm{O}$ and $\mathrm{BEs}$ of $534.6 \mathrm{eV}$ belongs to the oxygen atom bonded with $\mathrm{Cu}(\mathrm{C}=\mathrm{O}-\mathrm{Cu}$ ) (Figure $6 \mathrm{~b}$ ).
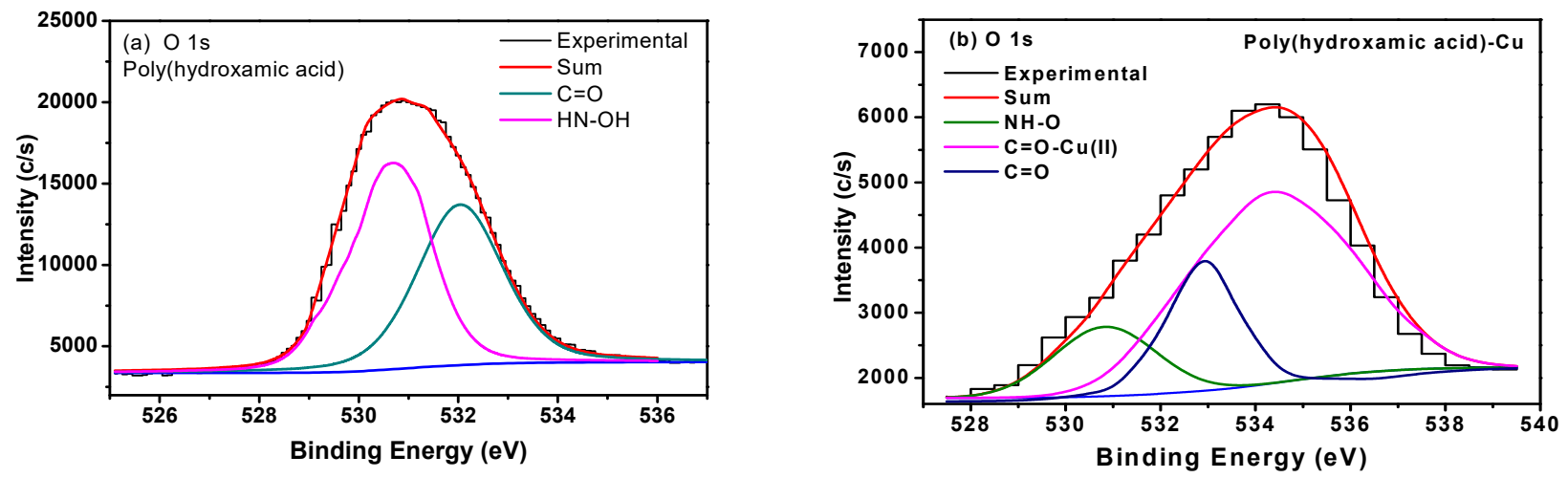

Figure 6. O1s core-level XPS spectra of (a) poly(hydroxamic acid) ligand and (b) poly(hydroxamic acid)-Cu(II) complex. 
On the other hand, we have performed another the core-level scan of 1s of nitrogen atom for the hydroxamic acid and its copper complex. In case of hydroxamic acid ligand, the BEs were at 398.9 and $400.6 \mathrm{eV}$ corresponding to the $\mathrm{N} 1 \mathrm{~s}$ for $\mathrm{N}-\mathrm{OH}$ and $\mathrm{N}-\mathrm{H}$ functional groups, respectively (Figure 7a). After complexation with copper, the BEs of $\mathrm{N} 1 \mathrm{~s}$ for $\mathrm{N}-\mathrm{OH}$ and $\mathrm{N}-\mathrm{H}$ were increased to 399.6 and $402.8 \mathrm{eV}$, respectively (Figure $7 \mathrm{~b}$ ). After complexation, the BEs of $\mathrm{N}-\mathrm{OH}$ and $\mathrm{N}-\mathrm{H}$ were also shifted to higher BEs, which confirmed that the nitrogen atom participated in the complex formation with copper species. These higher BEs were observed as electron donation properties of oxygen and nitrogen atoms at the ligand site resulted in the decreased electron density [39].
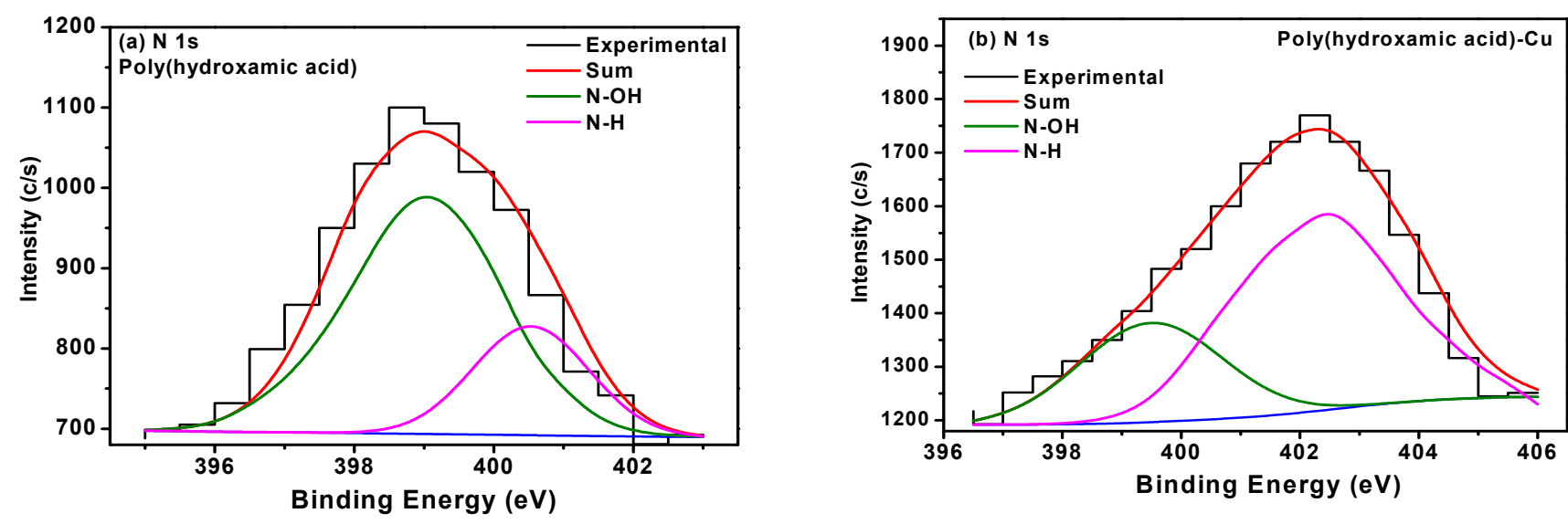

Figure 7. N1s core-level XPS spectra of (a) poly(hydroxamic acid) ligand and (b) poly(hydroxamic acid)-Cu(II) complex.

\subsection{Adsorption of Heavy Metal Ions \\ Effect of $\mathrm{pH}$ on the Adsorption}

A distinguishable $\mathrm{pH}$ effect on the adsorption capacity of the metal ions by the polymeric ligands was found when compared with the previous work $[23,25,40]$. The $\mathrm{pH}$ effect on the adsorption behavior was studied using various metals $\left(\mathrm{Cu}^{2+}, \mathrm{Co}^{2+}, \mathrm{Cr}^{3+}\right.$, and $\mathrm{Ni}^{2+}$ ) at room temperature with $\mathrm{pH}$ ranging from 3 to 6 . A series of the batch adsorption was performed with sodium acetate buffers solutions ( $\mathrm{pH} 3-6)$.

The adsorption capacity $q_{e}$ values were calculated as $\mathrm{mg} \cdot \mathrm{g}^{-1}$ based on Equation (1), and experimental data $q_{e}$ were plotted against various $\mathrm{pH}$ values (Figure 8). The $q_{e}$ was increased from $\mathrm{pH} 3$ to 6 , and optimum condition was found at $\mathrm{pH} 6$ for all metal ions. Thus, copper $\left(\mathrm{Cu}^{2+}\right)$ ions exhibited the highest binding ability as $346.7 \mathrm{mg} \cdot \mathrm{g}^{-1}$ at $\mathrm{pH} 6$, and other heavy metal ions showed adsorption capacities of $315,227.6$, and $181.4 \mathrm{mg} \cdot \mathrm{g}^{-1}$ for $\mathrm{Co}^{2+}, \mathrm{Cr}^{3+}$, and $\mathrm{Ni}^{2+}$, respectively. A noticeable increase in the adsorption ability can be observed from $\mathrm{pH} 3$ to 6 , showing that the binding event of metal ions by poly(hydroxamic acid) was $\mathrm{pH}$ dependent in the order of $\mathrm{Cu}^{2+}>\mathrm{Co}^{2+}>\mathrm{Cr}^{3+}>\mathrm{Ni}^{2+}$. The presence of bidentate hydroxamate anions created five-membered ring complexes with metal ions [25].

The adsorption uptake action by the polymer adsorbent was achieved due to the presence of hydroxamic acid group $-\mathrm{CH}_{2}(\mathrm{C}=\mathrm{O}) \mathrm{NH}(\mathrm{OH})[30,32]$. The binding event occurred due to low $\mathrm{pH}$ condition; the basic carbonyl group $(-\mathrm{C}=\mathrm{O})$ tends to be hindered from binding with the positively-charged heavy metal cations as protonation occurs at low $\mathrm{pH}$ as a result of higher concentration of $\mathrm{H}^{+}$, resulting in the formation of positively charged $\mathrm{C}=\mathrm{O}^{+}-\mathrm{H}$ functional group. In addition, at low $\mathrm{pH}$ conditions, the ionization of acidic hydroxyl group (-OH) is unlikely to occur. These events result in reduced adsorption strength of heavy metal ions because at low $\mathrm{pH}$ conditions, there is relatively high concentration of acidic $\mathrm{H}^{+}$cation, which competes with positively-charged heavy metal cations when adsorption occurs. Thus, adsorption uptake of heavy metal cations undergoes competition and they have lower affinity towards polymeric ligand at low $\mathrm{pH}$ conditions. On the contrary, in the acidic $\mathrm{pH}$ conditions ( $\mathrm{pH} 5-6$ ), the concentration of $\mathrm{H}^{+}$ions is relatively in the lower range. As a result, the protonation of oxygen in the basic $-\mathrm{C}=\mathrm{O}$ was less likely to 
occur. The coordination capability of carbonyl group of poly(hydroxamic acid) to metal ions was raised. Moreover, the ionization of acidic hydroxyl group $(-\mathrm{OH})$ was increased and negatively-charged oxygen ions were formed, which favored the electrostatic interaction between the hydroxamic acid resin and the heavy metal cations, causing a higher adsorption strength of polymeric ligand towards heavy metal ions, and thus, ultimately resulted in the formation of metal-ligand complexes $[27,28]$. On the other hand, solutions with $\mathrm{pH}$ greater than 7 could not determine the significance of the study due to the chances of hydrolysis and precipitation of transition metal ions. At basic condition, the precipitation of transition metal ions in the hydroxide form is induced due to higher $\mathrm{pH}$ values $(>7)$, therefore, concentration of metal ions can be lowered leading to the incorrect $q_{e}$ values.

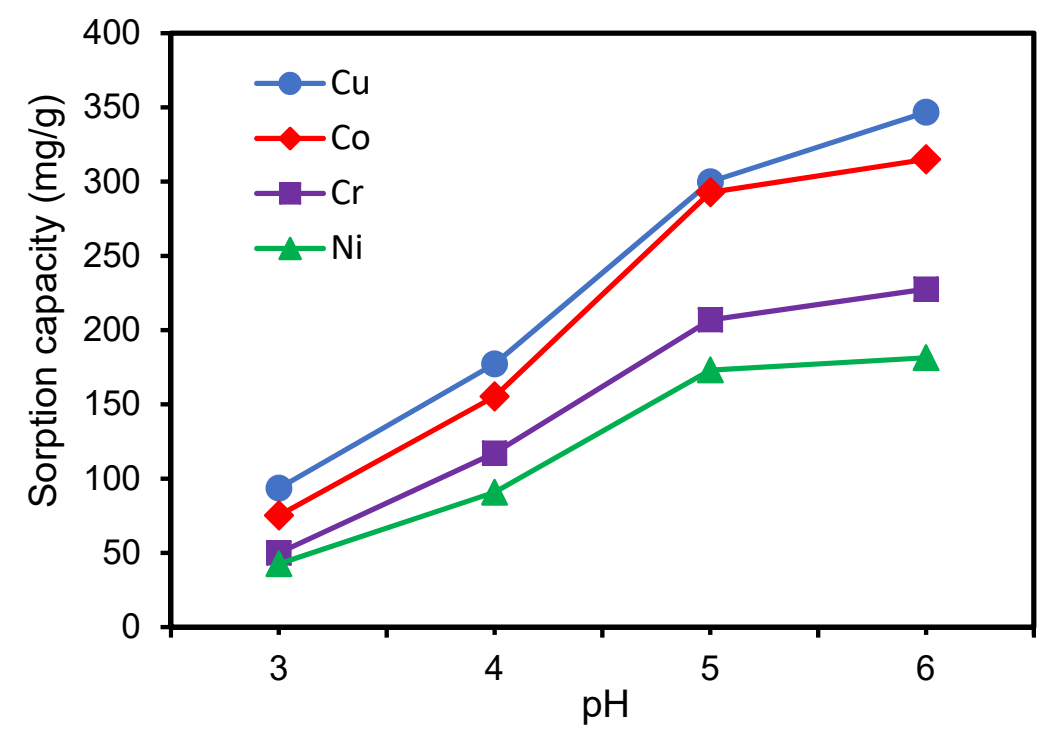

Figure 8. The plot of sorption capacity versus various $\mathrm{pH}$ by poly(hydroxamic acid); experimental conditions: $100 \mathrm{mg}$ of dried poly(hydroxamic acid), $10 \mathrm{~mL}$ of $0.1 \mathrm{M} \mathrm{CH}_{3} \mathrm{COONa}$ buffer solution at $\mathrm{pH} 3-6$, and $5 \mathrm{~mL}$ of $0.1 \mathrm{M}$ heavy metal ion solutions agitated for $2 \mathrm{~h}$.

\subsection{Adsorption Kinetic Studies}

In principle, adsorption process requires contact time by the adsorbent with the metal ions such as $\mathrm{Cu}^{2+}, \mathrm{Co}^{2+}, \mathrm{Cr}^{3+}$, and $\mathrm{Ni}^{2+}$. The kinetic $\left(q_{t}\right)$ adsorption capacity was determined for every interval period $(5,15,30,60$, and $120 \mathrm{~min})$, and ICP-OES was used for analysis of metal ions. Selected heavy metal ions were used for the kinetic study with poly(hydroxamic acid) ligand. Based on the kinetic study, the effect of $\mathrm{pH}$ on the sorption efficiency towards selected heavy metal ions was then determined at optimum $\mathrm{pH}$ condition ( $\mathrm{pH} 6$ ) for the complexation reaction [35]. Therefore, $\mathrm{pH} 6$ was used for studying the adsorption kinetics along others parameter described in Figure 9.

Figure 9 displayed the interrelation between the different reaction contact time and the adsorption capacities of poly(hydroxamic acid) ligand towards various metal ions. From the adsorption kinetic study curves, it was found that all the metal ions showed similar trend with the adsorbent as a function of time (Figure 9). It showed that there is increase in adsorption capacities with increase in contact time from 5 to $120 \mathrm{~min}$. Based on the graph, it can be seen that the uptake of $\mathrm{Cu}^{2+}$ ions by ligand exhibited the highest adsorption capacity at $120 \mathrm{~min}$ time interval $\left(304.5 \mathrm{mg} \cdot \mathrm{g}^{-1}\right)$, while other heavy metal ions such as $\mathrm{Co}^{2+}, \mathrm{Cr}^{3+}$, and $\mathrm{Ni}^{2+}$ also showed considerably good adsorption capacities, which were $282.1,209.1$, and $178.0 \mathrm{mg} \cdot \mathrm{g}^{-1}$, respectively.

As the time interval increased with adsorption kinetic studies via batch adsorption, agitation was required during the reaction as it increases the chances of uniform and even collision between the molecules of metal ions and the adsorbent. As a result, it increased the reaction rate. The adsorption mechanism involved the development of valance forces 
from the sharing and exchanging of electrons between the heavy metal ions involved and the poly(hydroxamic acid) ligand.

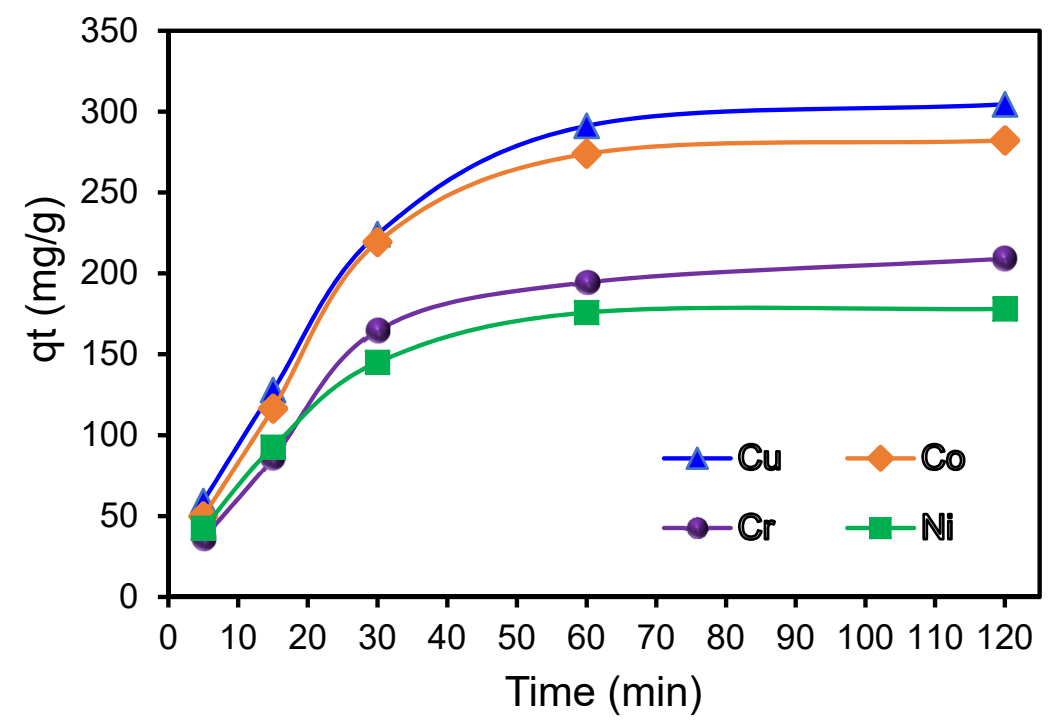

Figure 9. The effect of different binding contact time of selected metal ions by poly(hydroxamic acid); experimental conditions: $100 \mathrm{mg}$ of dried poly(hydroxamic acid), $10 \mathrm{~mL}$ of $0.1 \mathrm{M} \mathrm{CH}_{3} \mathrm{COONa}$ buffer solution at $\mathrm{pH} 6$, and $5 \mathrm{~mL}$ of $0.1 \mathrm{M}$ heavy metal solutions agitated for 5, 15, 30, 60, and $120 \mathrm{~min}$.

According to the graph obtained in Figure 9, the uptake of metal ions by adsorbent was at higher rate at the early time intervals. At initial time intervals of reaction, there were large numbers of the functional groups $(-\mathrm{NHOH}$ and $-\mathrm{C}=\mathrm{O})$ of poly(hydroxamic acid) ligand available to bind to the metal ions via coordination. The large number of active sites were available and free for binding of metal ions with the ligand [36]. The adsorption of metal ions by poly(hydroxamic acid) achieved equilibrium at $120 \mathrm{~min}$. This indicated that the adsorption reaction rate after the time interval of $120 \mathrm{~min}$ was negligibly slow and eventually stagnant.

\subsubsection{Pseudo-First-Order Rate of Reaction}

Determination of the rate of adsorption by the poly(hydroxamic acid) ligand involved either chemisorption or physisorption. Two common kinetic models, pseudo-first and pseudo-second-order rate of reactions, are utilized to study the adsorption kinetic behavior. Table 1 shows the pseudo-first-order rate of reaction model and its related kinetic parameters involved in the adsorption process.

Table 1. Pseudo-first-order rate of reaction for adsorption of heavy metal ions by poly(hydroxamic acid) ligand.

\begin{tabular}{|c|c|c|c|c|c|}
\hline \multirow{2}{*}{ Adsorbate } & \multicolumn{3}{|c|}{ Pseudo-First-Order } & \multirow{2}{*}{$\frac{\text { Experimental }}{q_{e}\left(\mathrm{mg} \cdot \mathrm{g}^{-1}\right)}$} & \multirow{2}{*}{$\begin{array}{c}\text { Differences } \\
\left(\mathrm{mg} \cdot \mathrm{g}^{-1}\right)\end{array}$} \\
\hline & $q_{t}\left(\mathrm{mg} \cdot \mathrm{g}^{-1}\right)$ & $K_{a d s}\left(\mathrm{~g} \cdot \mathrm{mg}^{-1} \mathrm{~min}\right)$ & $\mathbf{R}^{2}$ & & \\
\hline $\mathrm{Cu}$ & 242.4 & 0.01658 & 0.8538 & 346.7 & 104.3 \\
\hline Co & 213.1 & 0.01819 & 0.8223 & 315.0 & 101.9 \\
\hline $\mathrm{Cr}$ & 158.9 & 0.01981 & 0.8896 & 227.6 & 68.7 \\
\hline $\mathrm{Ni}$ & 111.9 & 0.03316 & 0.8643 & 181.4 & 69.5 \\
\hline
\end{tabular}

Equation (3) was used to find out the kinetic behavior of pseudo-first-order rate of adsorption.

$$
\log \left(q_{e}-q_{t}\right)=\log q_{e}-\left(\frac{K_{a d s}}{2.303}\right) t
$$


where $q_{e}$ and $q_{t}$ are the quantities of binding ions $\left(\mathrm{mg} \cdot \mathrm{g}^{-1}\right)$ at equilibrium and $t$ is the time (min) required for adsorption of metal ions. The pseudo-first-order rate constant $\left(\mathrm{min}^{-1}\right)$ is expressed by $K_{a d s}$. The extent of parameters for $q_{e}$ and $K_{a d s}$ were determined from the intercept and the slope of the graph (Figure 10) as $\log \left(q_{e}-q_{t}\right)$ versus time. The data obtained for the parameters with four metal ions are shown in Table 1. Based on the calculated data in Table 1 , the $\mathrm{R}^{2}$ values of $\mathrm{Cu}, \mathrm{Co}, \mathrm{Cr}$, and $\mathrm{Ni}$ were $0.8538,0.8223$, 0.8896 , and 0.8643 , respectively. The values are all insignificant $\left(R^{2}<0.89\right)$. On the other hand, the experimental adsorption $\left(q_{e}\right)$ and the calculated adsorption $\left(q_{t}\right)$ showed notable differences resulting in the pseudo-first-order rate of kinetic model being less fit to the experimental data.

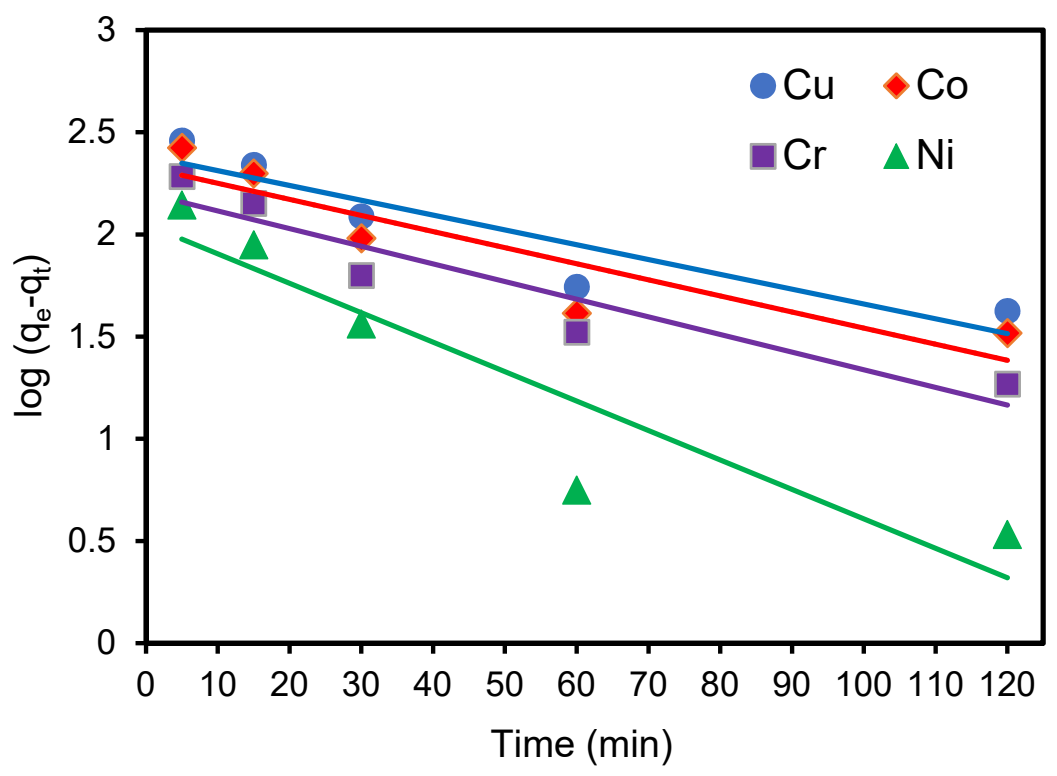

Figure 10. Pseudo-first-order kinetic plots of metal adsorption by polymer ligand; experimental conditions: $100 \mathrm{mg}$ of poly(hydroxamic acid), $10 \mathrm{~mL}$ of $0.1 \mathrm{M} \mathrm{CH}_{3} \mathrm{COONa}$ buffer solution, and $5 \mathrm{~mL}$ of $0.1 \mathrm{M}$ heavy metal solution at $\mathrm{pH} 6$ agitated for $2 \mathrm{~h}$.

\subsubsection{Pseudo-Second-Order Rate of Reaction}

Equation (4) was used to find out the kinetic behavior of pseudo-second-order rate of adsorption.

$$
\frac{t}{q_{t}}=\frac{1}{k_{2} q_{e}^{2}}+\frac{t}{q_{e}}
$$

where $q_{t}$ is the quantity of metal ions adsorption $\left(\mathrm{mg} \cdot \mathrm{g}^{-1}\right)$ at a time interval and the $q_{e}$ is the metal ions adsorbed $\left(\mathrm{mg} \cdot \mathrm{g}^{-1}\right)$ at equilibrium. In addition, $k_{2}$ is the pseudo-second-order rate constant $\left(\mathrm{g} \cdot \mathrm{mg}^{-1} \mathrm{~min}\right)$.

A plot of $t / q_{t}$ against time and the corresponding values of $k_{2}$ and $q_{e}$ were quantified from the graph (Figure 11). Based on the calculated results in Table 2, the $\mathrm{R}^{2}$ values of $\mathrm{Cu}, \mathrm{Co}, \mathrm{Cr}$, and $\mathrm{Ni}$ were $0.9877,0.9783,0.9812$, and 0.9920 , respectively, and they are in acceptable ranges $\left(R^{2}>0.98\right)$. Of all the correlation coefficient values, $R^{2}$ values were relatively large and showed high consistency. In addition, the experimental values $\left(q_{e}\right)$ of adsorption capacities of the metal ions were comparable with their respective calculated $q_{t}$ values. It can be observed that experimental adsorption $\left(q_{e}\right)$ and the calculated adsorption $\left(q_{t}\right)$ displayed minor differences of the pseudo-second-order rate of adsorption (Table 2). Therefore, kinetic data obtained from the graph suggested that the pseudosecond-order kinetic model was best fit with the experimental values. In conclusion, the pseudo-second-order rate of reaction kinetic was more predominant than pseudofirst-order kinetic. This kinetic behavior showed that the adsorption mechanism was chemically rate controlling [37,39]. Herein, the second-order mechanism is prevalent in the 
experimental data, therefore, the adsorption mechanism exhibited chemical process owing to the exchange of electrons between the metal ions and polymer ligand [39].

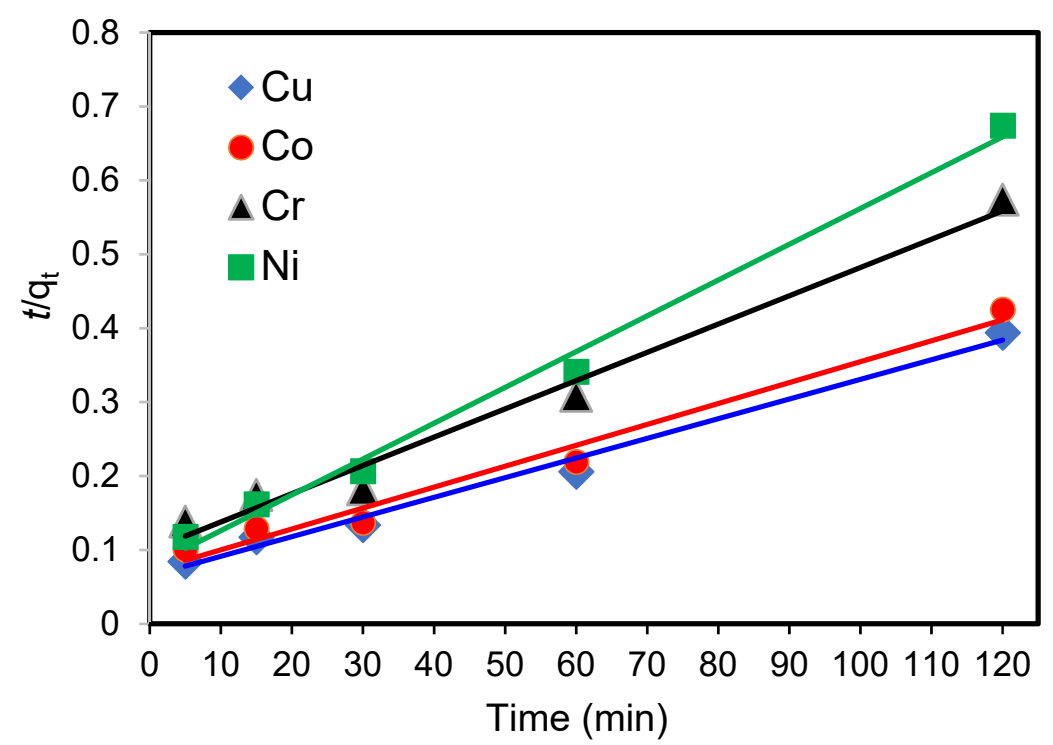

Figure 11. Pseudo-second-order kinetic plots of adsorption by polymer ligand; experimental conditions: $100 \mathrm{mg}$ of poly(hydroxamic acid), $10 \mathrm{~mL}$ of $0.1 \mathrm{M} \mathrm{CH}_{3} \mathrm{COONa}$ buffer solution, and $5 \mathrm{~mL}$ of $0.1 \mathrm{M}$ heavy metal at $\mathrm{pH} 6$ agitated for $2 \mathrm{~h}$.

Table 2. Pseudo-second-order rate of adsorption of metal ions by poly(hydroxamic acid) ligand.

\begin{tabular}{|c|c|c|c|c|c|}
\hline \multirow{2}{*}{ Adsorbate } & \multicolumn{3}{|c|}{ Pseudo-Second Order } & \multirow{2}{*}{$\begin{array}{c}\text { Experimental } \\
q_{e}\left(\mathrm{mg} \cdot \mathrm{g}^{-1}\right)\end{array}$} & \multirow{2}{*}{$\begin{array}{c}\text { Differences } \\
\left(\mathrm{mg} \cdot \mathrm{g}^{-1}\right)\end{array}$} \\
\hline & $q_{t}\left(\mathrm{mg} \cdot \mathrm{g}^{-1}\right)$ & $k_{2}\left(\mathrm{~g} \cdot \mathrm{mg}^{-1} \mathrm{~min}\right) \times 10^{-4}$ & $\mathbf{R}^{2}$ & & \\
\hline $\mathrm{Cu}$ & 370.4 & 1.1266 & 0.9877 & 346.7 & 23.7 \\
\hline Co & 357.1 & 1.0892 & 0.9783 & 315.0 & 42.1 \\
\hline $\mathrm{Cr}$ & 263.2 & 1.4493 & 0.9812 & 227.6 & 35.6 \\
\hline $\mathrm{Ni}$ & 208.3 & 2.9662 & 0.9920 & 181.4 & 26.9 \\
\hline
\end{tabular}

\subsection{Adsorption Isothermal Studies}

Commonly, the isothermal studies have been performed to find out the effect of initial concentrations of adsorbate on the adsorption capacity by the adsorbent. Therefore, a series of batch adsorption was performed using copper, cobalt, chromium, and nickel ions with various concentrations. In this study, except concentration of metal ions, other parameters were kept fixed as follows: $100 \mathrm{mg}$ of poly(hydroxamic acid) ligands was used, $\mathrm{pH}$ of the solutions were set at $\mathrm{pH}$ 6, and agitation time was set to $2 \mathrm{~h}$ with constant speed. The concentration of the metal ions was kept variable such as 10, 300, 600, and 1200-2400 ppm. Figure 12 displayed the adsorption capacity of poly(hydroxamic acid) ligands against the four heavy metal ions at different heavy metal solution concentrations. As expected, that the adsorption capacity towards the heavy metals was increased with the increase in initial concentration of heavy metals, which eventually reached the equilibrium after $1200 \mathrm{ppm}$. 


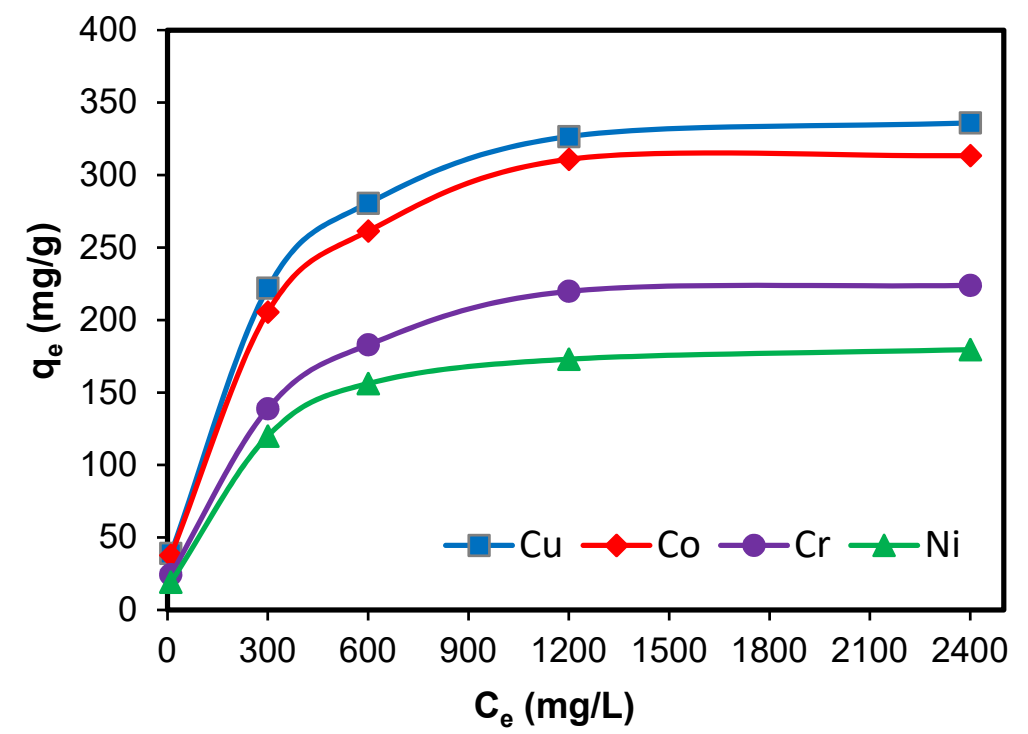

Figure 12. The effect of different initial heavy metals concentrations on adsorption by poly(hydroxamic acid) ligand; experimental conditions: $100 \mathrm{mg}$ of dried poly(hydroxamic acid), $5 \mathrm{~mL}$ of $0.1 \mathrm{M} \mathrm{CH}_{3} \mathrm{COONa}$ buffer solution, and $5 \mathrm{~mL}$ of $0.1 \mathrm{M}$ heavy metal solutions $(10,300,600$, 1200 and $2400 \mathrm{ppm}$ ) at $\mathrm{pH} 6$ agitated for $2 \mathrm{~h}$.

In the next subsection, we have studied some common isothermal studies for understanding the isothermal behaviors of the adsorption process. Therefore, most common isothermal models such as Langmuir isotherm model and Freundlich isotherm model were chosen to study the isothermal behaviors. Thus, common linear forms of Langmuir and Freundlich isotherm models were selected due to the mathematical simplicity of linear form model itself [32-34].

\subsubsection{Linear Langmuir Adsorption Isotherm}

Langmuir adsorption isotherm model have been used to determine the monolayer adsorption; thus, Langmuir model is fit to the four criteria such as uniform surface and equivalent adsorption sites, no interaction of adsorbed molecules, adsorption mechanism is unique, and single layer or monolayer adsorption take place on the surface of the adsorbate $[33,34]$. The linear form of Langmuir adsorption isotherm is stated as Equation (5):

$$
\frac{C_{e}}{q_{e}}=\frac{1}{q_{\max } K_{L}}+\frac{C_{e}}{q_{\max }}
$$

where $C_{e}$ stands for the equilibrium metal ions concentration $\left(\mathrm{mg} \cdot \mathrm{L}^{-1}\right), q_{e}$ stands for the equilibrium adsorption capacity $\left(\mathrm{mg} \cdot \mathrm{g}^{-1}\right)$ with corresponding metal ions solution, $K_{L}$ stands for Langmuir adsorption constant $\left(\mathrm{L} \mathrm{mg}^{-1}\right)$, and $q_{\max }$ is the maximum capacity $\left(\mathrm{mg} \mathrm{g}^{-1}\right)$ of the adsorbent.

Accordingly, the $q_{e}$ values were determined from the slopes of graph and Langmuir constant $K_{L}$ was calculated from the intercepts of the linear plots using the parameter $C_{e} / q_{e}$ versus $C_{e}$ (Figure 13). Based on the data furnished in Table 3 , all the correlation coefficient $\left(\mathrm{R}^{2}\right)$ were significantly in accordance with Langmuir model $\left(\mathrm{R}^{2}>0.99\right)$. The magnitudes of metals ions adsorption are in the order of $\mathrm{Cu}^{2+}>\mathrm{Co}^{2+}>\mathrm{Cr}^{3+}>\mathrm{Ni}^{2+}$ corresponding to values of 357.1, 333.3, 238.1, and $185.2 \mathrm{mg} / \mathrm{g}$, respectively (Table 3). This adsorption order was exactly similar with the order recorded in the previous $\mathrm{pH}$ and kinetic studies. In addition, the adsorption values calculated from Langmuir model showed very little differences with the experimental adsorption obtained previously. Since all of them were having $\mathrm{R}^{2}>0.99$, it was indicated that single or monolayer adsorption have been occurred on the surface of the adsorbent. 


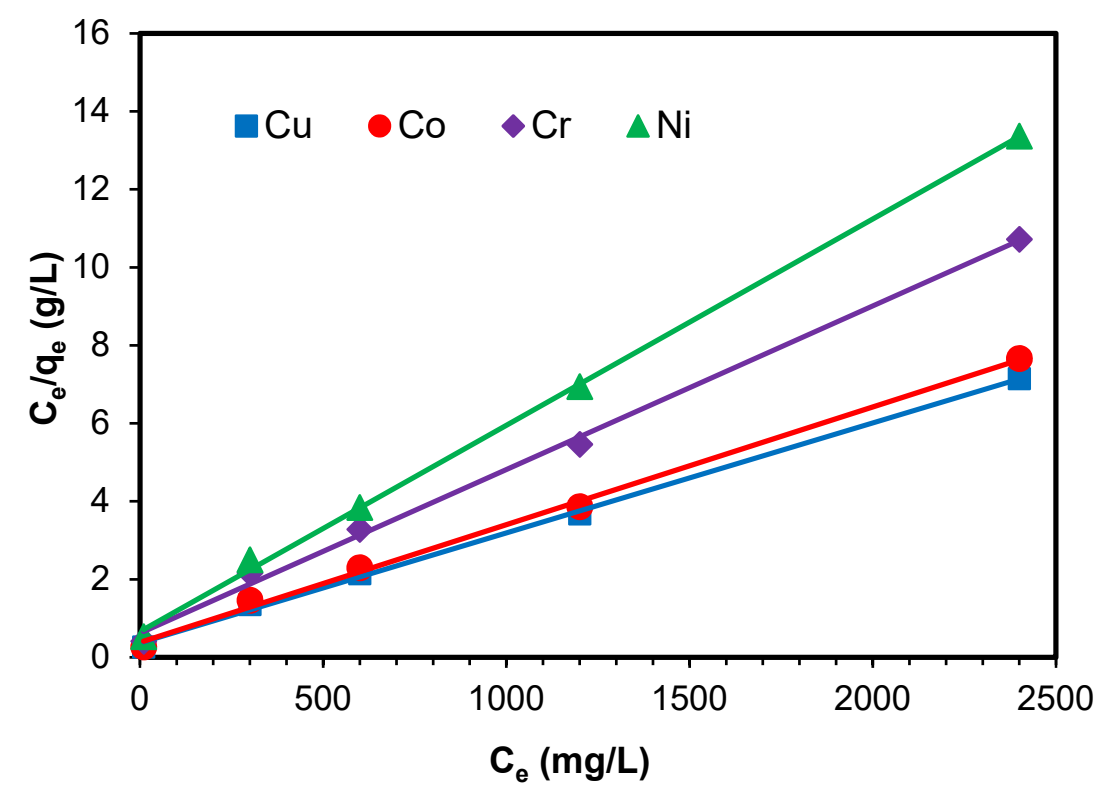

Figure 13. Linear plots of Langmuir adsorption isotherm by poly(hydroxamic acid) ligand; experimental conditions: $100 \mathrm{mg}$ of poly(hydroxamic acid), $5 \mathrm{~mL}$ of $0.1 \mathrm{M} \mathrm{CH}_{3} \mathrm{COONa}$ buffer solution, and $5 \mathrm{~mL}$ of $0.1 \mathrm{M}$ heavy metal solutions (10, 300, 600, 1200 and $2400 \mathrm{ppm})$ at pH 6 agitated for $2 \mathrm{~h}$.

Table 3. Langmuir adsorption isotherm (linear) parameters of poly(hydroxamic acid) ligand.

\begin{tabular}{|c|c|c|c|c|}
\hline \multirow{2}{*}{ Adsorbent } & \multicolumn{3}{|c|}{ Langmuir } & \multirow{2}{*}{$\begin{array}{l}\text { Difference with } \\
q_{m}\left(\mathrm{mg} \cdot \mathrm{g}^{-1}\right)\end{array}$} \\
\hline & $q_{e}\left(\mathrm{mg} \cdot \mathrm{g}^{-1}\right)$ & $K_{L}\left(\mathrm{~L} \cdot \mathrm{g}^{-1}\right)$ & $\mathbf{R}^{2}$ & \\
\hline $\mathrm{Cu}^{2+}$ & 357.1 & 0.008112 & 0.999 & 10.4 \\
\hline $\mathrm{Co}^{2+}$ & 333.3 & 0.007797 & 0.997 & 18.3 \\
\hline $\mathrm{Cr}^{3+}$ & 238.1 & 0.007348 & 0.996 & 10.5 \\
\hline $\mathrm{Ni}^{2+}$ & 185.2 & 0.009878 & 0.998 & 3.8 \\
\hline
\end{tabular}

\subsubsection{Linear Freundlich Adsorption Isotherm}

In principle Freundlich isotherm model have been used to rationalize the multiple layer adsorption in the heterogenous system of the adsorbent surface [34]. A linear Freundlich isotherm equation is conveyed in Equation (6).

$$
\log q_{e}=\log K_{F}+\frac{\log C_{e}}{n}
$$

In Equation (6), the $q_{e}$ and $C_{e}$ stand for adsorption capacity (mg/g) and equilibrium adsorption capacity $\left(\mathrm{mg} \cdot \mathrm{L}^{-1}\right)$, respectively, as described in previous equation. Here, $K_{F}$ is Freundlich's constant, and $1 / \mathrm{n}$ is the heterogeneity factor.

The linear plots of Freundlich adsorption isotherm are used to find the parameters in the heterogenous system. Therefore, the heterogeneity factor $n$ values were determined from the slopes of the graph, and the $K_{F}$ values were estimated from the intercepts of the graph using the plots of $\log q_{e}$ versus $\log C_{e}$ (Figure 14). The data associated with the graph are presented in Table 4 . The overall data values of correlation coefficient were not well fitted $\left(R^{2}<0.96\right)$. In comparison with both isotherm models, Freundlich isotherm was less significant compared to that of Langmuir isotherm, indicating that it was unlikely to have multilayer adsorption on the heterogeneous surface of the poly(hydroxamic acid) ligand. 


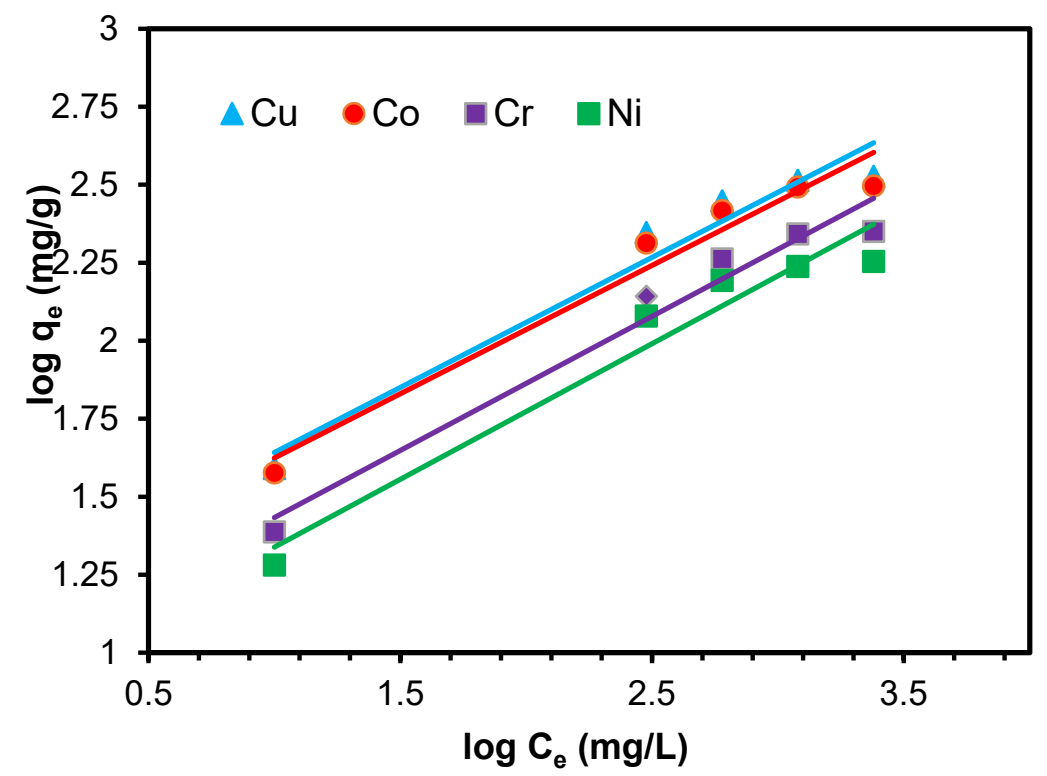

Figure 14. Linear plots of Freundlich adsorption isotherm by poly(hydroxamic acid) ligand; experimental conditions: $100 \mathrm{mg}$ of poly(hydroxamic acid), $5 \mathrm{~mL}$ of $0.1 \mathrm{M} \mathrm{CH}_{3} \mathrm{COONa}$ buffer solution, and $5 \mathrm{~mL}$ of $0.1 \mathrm{M}$ heavy metal solutions $(10,300,600,1200$, and $2400 \mathrm{ppm})$ at $\mathrm{pH} 6$ agitated for $2 \mathrm{~h}$.

Table 4. Freundlich adsorption isotherm (linear) parameters of poly(hydroxamic acid) ligand.

\begin{tabular}{cccc}
\hline \multirow{2}{*}{ Adsorbent } & \multicolumn{3}{c}{ Freundlich } \\
\cline { 2 - 4 } & $\mathbf{n}$ & $\boldsymbol{K}_{\boldsymbol{F}} \mathbf{( L \cdot \mathbf { m g }} \mathbf{g}^{\mathbf{- 1}}$ & $\mathbf{R}^{\mathbf{2}}$ \\
\hline $\mathrm{Cu}^{2+}$ & 2.6853 & 22.8034 & 0.958 \\
$\mathrm{Co}^{2+}$ & 2.4307 & 16.323 & 0.959 \\
$\mathrm{Cr}^{3+}$ & 2.7563 & 16.0029 & 0.965 \\
$\mathrm{Ni}^{2+}$ & 3.3944 & 21.0039 & 0.950 \\
\hline
\end{tabular}

According to the calculated results presented in Table 5, it can be noticed that the Langmuir model had smaller HYBRID and MPSD values. Smaller HYBRID and MPSD values indicated smaller error in the estimation of $q_{e}$ values in the isotherm model. As a result, Langmuir model had more accurate and less error of estimating $q_{e}$ values, suggesting that Langmuir isotherm model was the best fit model and provided a better model of explaining the isothermal behavior of adsorption of heavy metal ions by the polymer ligand.

Table 5. Isotherm parameters and error functions for adsorption of heavy metals onto poly(hydroxamic acid) ligand.

\begin{tabular}{|c|c|c|c|c|c|}
\hline \multirow{2}{*}{ Adsorbent } & \multicolumn{5}{|c|}{ Langmuir } \\
\hline & $q_{e}\left(\mathrm{mg} \cdot \mathrm{g}^{-1}\right)$ & $K_{L}\left(\mathrm{~L} \cdot \mathrm{mg}^{-1}\right)$ & $\mathbf{R}^{2}$ & HYBRID & MPSD \\
\hline $\mathrm{Cu}$ & 357.1 & 0.008112 & 0.999 & 0.1759 & 20.0614 \\
\hline Co & 333.3 & 0.007797 & 0.997 & 0.1961 & 21.5535 \\
\hline $\mathrm{Cr}$ & 238.1 & 0.007348 & 0.996 & 0.2022 & 22.1535 \\
\hline $\mathrm{Ni}$ & 185.2 & 0.009878 & 0.998 & 0.1067 & 11.6378 \\
\hline
\end{tabular}

\subsection{Reusability Study of Poly(hydroxamic acid) Ligand}

Herein, the bio-waste materials were used as the source of cellulose materials to obtain the cellulose-based poly(hydroxamic acid) ligand; however, reusability study is essential to make sure its use in real-life applications. Reusability study comprehended the chemical process of elution and regeneration of the adsorbent. Based on the studies done on the $\mathrm{pH}$ 
effect on the adsorption by bio-adsorbent, it has been determined that the sorption of metal ions is unlikely to occur at very low $\mathrm{pH}$ as it is more prone to desorption process where the adsorbed metals can be desorbed out from the adsorbent $[23,24]$. Thus, by applying this concept, a $2 \mathrm{M}$ of $\mathrm{HCl}$ solution was used to desorbed metal cations from the adsorbent [24]. Therefore, cobalt-poly(hydroxamic acid) complex was desorbed using $\mathrm{HCl}$, and it was reused for a new adsorption cycle. The adsorption-desorption processes were performed for 6 cycles.

According to the adsorption capacity obtained earlier, the $\mathrm{Co}^{2+}$ optimum capacity was $315.0 \mathrm{mg} \cdot \mathrm{g}^{-1}$, and as referred to this result, \% sorption was calculated for each cycle. Based on the results displayed in Figure 15, the efficiencies of sorption and extraction based on the percentage of sorption and extraction data obtained were only having approximately $5 \%$ loss after 6 cycles of adsorption-desorption processes. According to the results, no significant loss of the adsorption capacity was found. In conclusion, the adsorbent indeed showed recyclable characteristic. Therefore, it is worthy to promote it in the removal of toxic metal ions from industrial wastewaters.

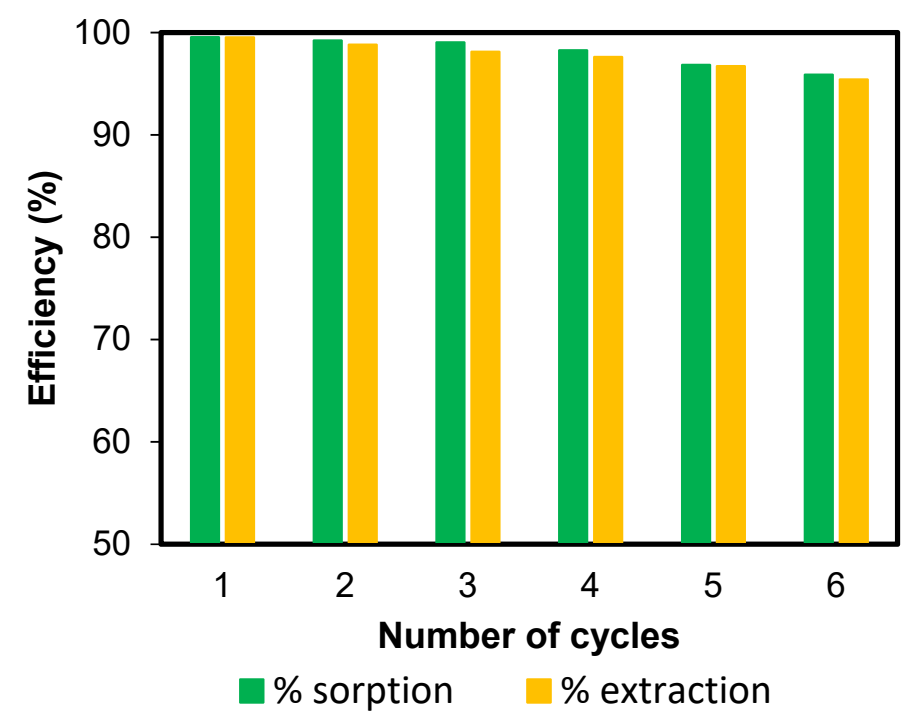

Figure 15. Reusability study of poly(hydroxamic acid) ligand in 6 cycles of adsorption-desorption of cobalt ions.

\subsection{Practical Application of Poly(hydroxamic acid) Ligand}

As determined by several parameters such as $\mathrm{pH}$, contact time, concentration of adsorbate, etc., the study the practical application of the adsorbent for removal of metal ions in real-life application is simple. The ICP-OES results showed (Table 6) that the couple of metal ions were present in wastewater samples (IWS 1 and IWS 2) obtained from a semiconductor electroplating industry in Singapore. Table 6 and Figure 16 demonstrated that the quantity of metal ions in the wastewater samples (ppm) was diminished dramatically after treatment with the polymer adsorbent at optimum conditions. It was observed that the removal of metal ions was fruitful and noteworthy.

The metal ions elimination capability of $\mathrm{Fe}^{3+}$ was higher, i.e., its removal efficiency was more than $95 \%$, while removal efficiency of $\mathrm{Cu}^{2+}, \mathrm{Pb}^{2+}$, and $\mathrm{Zn}^{2+}$ was approximately $80-90 \%$. Other heavy metal ions such as $\mathrm{Cr}^{3+}, \mathrm{Mn}^{2+}$, and $\mathrm{Ni}^{2+}$ were also having removal efficiency of more than $60-70 \%$ for IWS 2. On the other hand, $\mathrm{Cr}^{3+}$ itself in IWS 2 had even more removal efficiency ( $>96 \%$ ); in addition, $\mathrm{Fe}^{3+}$ and $\mathrm{Cu}^{2+}$ showed removal efficiency of $99 \%$ and $97 \%$, respectively, indicating that the elimination capability of heavy metal ions by poly(hydroxamic acid) ligand is potential. Several heavy metals including alkali and alkaline earth metals $\left(\mathrm{Ba}^{2+}, \mathrm{Ca}^{2+}, \mathrm{Mg}^{2+}, \mathrm{K}^{+}, \mathrm{Rb}^{+}, \mathrm{Na}^{+}, \mathrm{Ag}^{+}, \mathrm{V}^{4+}\right.$, and $\left.\mathrm{Al}^{3+}\right)$ showed reduction of metal ions after treatment with the adsorbent. However, the removal was relatively lower and less significant compared to that of the removal of heavy metal 
ions. In summary of practical application, poly(hydroxamic acid) can be used as an effective adsorbent, which is the most practical way of removing toxic metal ions from the industrial wastewaters.

Table 6. Compositions of metal ions in two wastewater samples (IWS 1 and IWS 2) collected from electroplating factory in Singapore before and after treatment by the adsorbent.

\begin{tabular}{|c|c|c|c|c|c|c|}
\hline \multirow[b]{2}{*}{ Metal Ions } & \multicolumn{3}{|c|}{ IWS 1} & \multicolumn{3}{|c|}{ IWS 2} \\
\hline & $\begin{array}{l}\text { Before Treatment } \\
(\mathrm{ppm})\end{array}$ & $\begin{array}{l}\text { After Treatment } \\
\quad(p p m)\end{array}$ & $\begin{array}{c}\% \\
\text { Removal }\end{array}$ & $\begin{array}{l}\text { Before Treatment } \\
(\text { (ppm) }\end{array}$ & $\begin{array}{l}\text { After Treatment } \\
(\mathrm{ppm})\end{array}$ & $\begin{array}{c}\% \\
\text { Removal }\end{array}$ \\
\hline $\mathrm{Fe}^{3+}$ & 32.0095 & 1.3896 & 95.66 & 1.4637 & 0.0076 & 99.48 \\
\hline $\mathrm{Cu}^{2+}$ & 23.0493 & 2.2051 & 90.43 & 85.7627 & 2.1787 & 97.46 \\
\hline $\mathrm{Pb}^{2+}$ & 0.0207 & 0.0021 & 90.34 & 0.1331 & 0.0356 & 73.25 \\
\hline $\mathrm{Zn}^{2+}$ & 0.0421 & 0.0081 & 81.01 & 0.1037 & 0.0084 & 91.93 \\
\hline $\mathrm{Cr}^{3+}$ & 0.0268 & 0.0059 & 77.85 & 0.0857 & 0.0031 & 96.34 \\
\hline $\mathrm{Mn}^{2+}$ & 0.1296 & 0.0296 & 77.17 & 0.0055 & 0.0013 & 75.47 \\
\hline $\mathrm{Ni}^{2+}$ & 0.01828 & 0.0064 & 65.23 & 0.4421 & 0.1364 & 69.14 \\
\hline $\mathrm{Ba}^{2+}$ & 0.0013 & 0.0007 & 48.42 & - & - & - \\
\hline $\mathrm{Ca}^{2+}$ & 0.5517 & 0.2948 & 46.56 & 0.8918 & 0.4191 & 53.01 \\
\hline $\mathrm{Rb}^{+}$ & 0.0305 & 0.0180 & 40.30 & 0.0109 & 0.0066 & 38.78 \\
\hline $\mathrm{K}^{+}$ & 0.0783 & 0.0544 & 30.45 & 0.2791 & 0.1877 & 32.72 \\
\hline $\mathrm{Na}^{+}$ & 15.23 & 12.38 & 18.70 & 9.7411 & 8.2496 & 15.31 \\
\hline $\mathrm{V}^{4+}$ & 0.00006 & 0.000055 & 9.01 & - & - & - \\
\hline $\mathrm{Al}^{3+}$ & 0.0505 & 0.0474 & 6.09 & 0.0063 & 0.0059 & 6.64 \\
\hline $\mathrm{Ag}^{+}$ & - & - & - & 0.0322 & 0.0141 & 56.25 \\
\hline $\mathrm{Mg}^{2+}$ & - & - & - & 0.0879 & 0.0520 & 40.83 \\
\hline
\end{tabular}

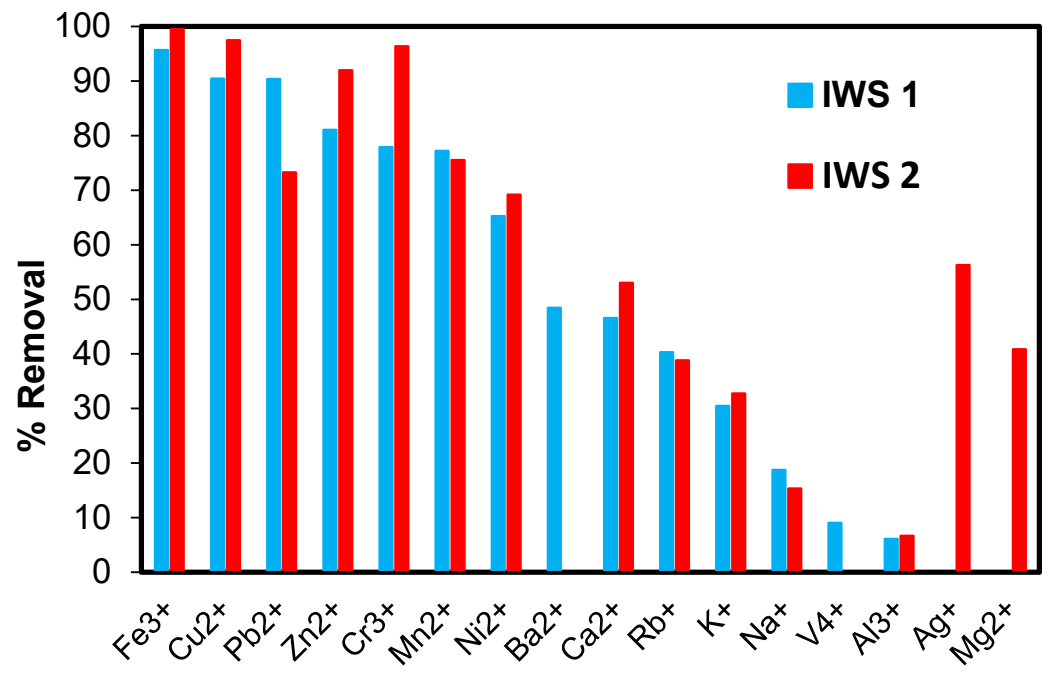

Figure 16. Removal of metal ions in industrial wastewater samples by poly(hydroxamic acid) ligand.

In principle, a ligand possessing a pair of non-bonding electrons belongs to the ions or molecules, which surrounds to the central metal atom to form a complex/coordination compound. Owing to the interest in toxic metal removal from wastewaters, a polymeric ligand, namely, the hydroxamic acid ligand, was derived from the modified waste fiber cellulose. Thus, a lone pair of electrons exists on the nitrogen and oxygen atoms of the hydroxamic acid groups that loses a lone pair of electrons, which co-ordinates with metal ions [23]. The cellulose moderation into the metal-binding ligands exhibits notable differences observed in the sorption magnitude. Various mechanisms of metal binding, including ion exchange, complexation, co-ordination/chelation, electrostatic interactions, etc., are known to us [25]. The binding properties of modified cellulose-based poly(hydroxamic acid) ligand is greatly affected by the types of metals and other conditions of sorption process [30,31]. 


\section{Conclusions}

The poly(hydroxamic acid) chelating ligand was synthesized by utilizing the extracted cellulose from waste fruit fibers, in which the durian fruit was edible but pandanus fruit was not edible. A series of adsorption studies such as effect of $\mathrm{pH}$, reaction contact time (kinetic), isotherm study, ligand reusability, and hands-on usefulness of the ligand was performed. Based on this study, it is found that the adsorption of copper, cobalt, chromium, and nickel by the adsorbent is all $\mathrm{pH}$ dependent. According to the results of kinetic study obtained in this study, the adsorption process by the ligand followed pseudo-second-order rate of reaction compared to the pseudo-first-order rate of reaction. The isothermal studies performed in this study also showed that the adsorption isothermal behavior is best fit with Langmuir adsorption isotherm model $\left(\mathrm{R}^{2}>0.99\right)$, suggesting that the synthesized poly(hydroxamic acid) ligand has homogenous surface and monolayer adsorption occurred on the ligand surface. Eventually, the practical metals waste showed excellent removal of metals, i.e., up to $90-99 \%$ of toxic metal ions was removed from industrial wastewater.

Author Contributions: Methodology, Z.-J.W.; formal analysis, C.G.J.; investigation, S.E.A.; resources, B.M.; writing-original draft preparation, M.L.R.; project administration, M.S.S.; funding acquisition, M.H.A. All authors have read and agreed to the published version of the manuscript.

Funding: This research was supported by the Skim UMSGreat, funding no. GUG0350-1/2019.

Institutional Review Board Statement: Not applicable.

Informed Consent Statement: Not applicable.

Data Availability Statement: The data presented in this study are available on request from the corresponding author.

Conflicts of Interest: The author declared no conflicts of interest.

\section{References}

1. Ajibade, F.O.; Adelodun, B.; Lasisi, K.H.; Fadare, O.O.; Ajibade, T.F.; Nwogwu, N.A.; Sulaymon, I.D.; Ugya, A.Y.; Wang, H.C.; Wang, A. Environmental pollution and their socioeconomic impacts. In Microbe Mediated Remediation of Environmental Contaminants; Elsevier: Amsterdam, The Netherlands, 2017. [CrossRef]

2. Jaishankar, M.; Tseten, T.; Anbalagan, N.; Mathew, B.B.; Beeregowda, K.N. Toxicity, mechanism and health effects of some heavy metals. Interdiscip. Toxicol. 2014, 7, 60-72. [CrossRef] [PubMed]

3. Jacob, J.M.; Karthik, C.; Saratale, R.G.; Kumar, S.S.; Prabakar, D.; Kadirvelu, K.; Pugazhendhi, A. Biological approaches to tackle heavy metal pollution: A survey of literature. J. Environ. Manag. 2018, 217, 56-70. [CrossRef] [PubMed]

4. Gunatilake, S.K. Methods of Removing Toxic Metals for Industrial Wastewater. J. Multi. Eng. Sci. Stud. 2015, 1, 12-18.

5. Rahman, M.L.; Sarkar, S.M.; Farida, E.M.; Arshad, S.E.; Sarjadi, M.S.; Wid, N. Synthesis of tapioca cellulose-based poly(amidoxime) ligand for removal of heavy metal ions. J. Macromol. Sci. Part B Phys. 2018, 57, 83-99. [CrossRef]

6. Fu, J.; Zhao, C.; Luo, Y.; Liu, C.; Kyzas, G.Z.; Luo, Y.; Zhao, D.; An, S.; Zhu, H. Heavy metals in surface sediments of the Jialu River, China: Their relations to environmental factors. J. Hazard. Mater. 2014, 270, 102-109. [CrossRef] [PubMed]

7. Rahman, M.L.; Rohani, N.N.M.; Yusoff, M.M. Synthesis of polyamidoxime chelating ligand from polymer-grafted corn-cob cellulose for metal extraction. J. Appl. Polym. Sci. 2014, 131, 40833. [CrossRef]

8. Pan, Y.; Shi, X.; Cai, P.; Guo, T.; Tong, Z.; Xiao, H. Dye removal from single and binary systems using gel-like bioadsorbent based on functional-modified cellulose. Cellulose 2018, 25, 2559-2575. [CrossRef]

9. Lin, G.; Wang, S.; Zhang, L.; Hu, T.; Peng, J.; Cheng, S.; Fu, L. Selective recovery of Au (III) from aqueous solutions using 2-aminothiazole functionalized corn bract as low-cost bioadsorbent. J. Clean. Prod. 2018, 196, 1007-1015. [CrossRef]

10. Chen, X.; Liu, L.; Luo, Z.; Shen, J.; Ni, Q.; Yao, J. Facile preparation of a cellulose-based bioadsorbent modified modified by hPEI in heterogenous system for high-efficiency removal of multiple types of dyes. React. Funct. Polym. 2018, 125, 77-83. [CrossRef]

11. Dos Santos Silva, L.; de Oliveira Carvalho, J.; de Sousa Bezerra, R.D.; Da Silva, M.S.; Ferreira, F.J.L.; Osajima, J.A.; da Silva Filho, E.C. Potential of cellulose functionalized with carboxylic acid as biosorbent for the removal of cationic dyes in aqueous solution. Molecules 2018, 23, 743. [CrossRef]

12. Lakherwal, D. Adsorption of Toxic Metals: A Review. Int. J. Environ. Res. Dev. 2014, 4, 41-48.

13. Lin, L.; Jin, P.X.; Yu, J.L.; Qin, Z.; Ju, M.Y. Three-dimensional macroporous cellulose-based bioadsorbents for efficient removal of nickel ions from aqueous solution. Cellulose 2016, 23, 723-736.

14. Wang, F.; Zhu, Y.; Wang, A. Preparation of carboxymethyl cellulose-g-poly (acrylamide)/attapulgite porous monolith with an eco-friendly pickering-mipe template for Ce(III) and Gd(III) adsorption. Front. Chem. 2020, 8, 398. [CrossRef] 
15. Hajeeth, T.; Vijayalakshmi, K.; Gomathi, T.; Sudha, P.N. Removal of Cu (II) and Ni (II) using cellulose extracted from sisal fiber and cellulose-g-acrylic acid copolymer. Int. J. Biol. Macromol. 2013, 62, 59-65. [CrossRef] [PubMed]

16. Mnasri-Ghnimi, S.; Frini-Srasra, N. Removal of toxic metals from aqueous solutions by adsorption using single and mixed pillared clays. Appl. Clay Sci. 2019, 179, 105151. [CrossRef]

17. Zhang, Y.; Duan, X. Chemical precipitation of toxic metals from wastewater by using the synthetical magnesium hydroxy carbonate. Water Sci. Technol. 2020, 81, 1130-1136. [CrossRef]

18. Tang, X.; Zheng, H.; Teng, H.; Sun, Y.; Guo, J.; Xie, W. Chemical coagulation process for the removal of toxic metals from water: A review. Desalin. Water Treat. 2016, 57, 1733-1748. [CrossRef]

19. Bashkim, S.T.; Salih, T.G. Reverse osmosis removal of toxic metals from wastewater effluents using biowaste materials pretreatment. Pol. J. Environ. Stud. 2019, 28, 337-341.

20. Khulbe, K.C.; Matsuura, T. Removal of toxic metals and pollutants by membrane adsorption techniques. Appl. Water Sci. 2019, 8, 19. [CrossRef]

21. Gupta, V.K.; Carrott, P.J.; Singh, R.; Chaudhary, M.; Kushwaha, S. Cellulose: A review as natural, modified and activated carbon adsorbent. Bioresour. Technol. 2016, 216, 1066.

22. Kang, H.; Liu, R.; Huang, Y. Graft modification of cellulose: Methods, properties and applications. Polymer 2015, 70, A1-A16. [CrossRef]

23. Rahman, M.L.; Sarkar, S.M.; Yusoff, M.M.; Abdullah, M.H. Optical detection and efficient removal of transition metal ions from water using poly (hydroxamic acid) ligand. Sens. Actuators B Chem. 2017, 242, 595-608. [CrossRef]

24. Rahman, M.L.; Fui, C.J.; Sarjadi, M.S.; Arshad, S.E.; Musta, B.; Abdullah, M.H.; Sarkar, S.M.; O’Reilly, E.J. Poly (amidoxime) ligand derived from waste palm fiber for the removal of toxic metals from electroplating wastewater. Environ. Sci. Pollut. Res. 2020, 27, 34541-34556. [CrossRef]

25. Rahman, M.L.; Wong, Z.J.; Sarjadi, M.S.; Abdullah, M.H.; Heffernan, M.A.; Sarkar, M.S.; O’Reilly, E. Poly (hydroxamic acid) ligand from palm-based waste materials for removal of toxic metals from electroplating wastewater. J. Appl. Polym. Sci. 2020, 182, 49671.

26. Dmitrii, S.B.; Nadezhda, A.B.; Vadim, Y.K. Coordination chemistry and metal-involving reactions of amidoximes: Relevance to the chemistry of oximes and oxime ligands. Coord. Chem. Rev. 2016, 313, 62-93.

27. Agrawal, Y.K. Hydroxamic acids and their metal complexes. Russ. Chem. Rev. 1979, 48, 948-963. [CrossRef]

28. Rachel, C. Traversing the coordination chemistry and chemical biology of hydroxamic acids. Coord. Chem. Rev. 2008, 252, 1387-1408.

29. Rahman, M.L.; Sarkar, S.M.; Yusoff, M.M.; Abdullah, M.H. Efficient removal of transition metal ions using poly(amidoxime) ligand from polymer grafted kenaf cellulose. RSC Adv. 2016, 6, 745-757. [CrossRef]

30. Rahman, M.L.; Mandal, B.H.; Sarkar, S.M.; Yusoff, M.M.; Arshad, S.; Musta, B. Synthesis of poly(hydroxamic acid) ligand from polymer grafted corn-cob cellulose for transition metals extraction. Polym. Adv. Technol. 2016, 27, 1625-1636. [CrossRef]

31. Rahman, M.L.; Biswas, T.K.; Sarkar, S.M.; Yusoff, M.M.; Sarjadi, M.S.; Arshad, S.E.; Musta, B. Adsorption of rare earth metals from water using a kenaf cellulose-based poly(hydroxamic acid) ligand. J. Mol. Liq. 2017, 243, 616-623. [CrossRef]

32. Rahman, M.L.; Mandal, B.H.; Sarkar, S.M.; Wahab, N.A.A.; Yusoff, M.M.; Arshad, S.E.; Musta, B. Synthesis of poly(hydroxamic acid) ligand from polymer grafted khaya cellulose for transition metals extraction. Fibers Polym. 2016, 17, 521-532. [CrossRef]

33. Swenson, H.; Stadie, N.P. Langmuir's Theory of Adsorption: A Centennial Review. Langmuir 2019, 35, 5409-5426. [CrossRef]

34. Appel, J. Freundlich's Adsorption Isotherm. Surf. Sci. 1973, 39, 237-244. [CrossRef]

35. Pan, Y.; Wang, F.; Wei, T.; Zhang, C.; Xiao, H. Hydrophobic modification of bagasse cellulose fibers with cationic latex: Adsorption kinetics and mechanism. Chem. Eng. J. 2016, 302, 33-43. [CrossRef]

36. Zheng, L.; Dang, Z.; Yi, X.; Zhang, H. Equilibrium and kinetic studies of adsorption of Cd (II) from aqueous solution using modified corn stalk. J. Hazard. Mater. 2010, 176, 650-656. [CrossRef] [PubMed]

37. Awual, M.R.; Yaita, T.; El-Safty, S.A.; Shiwaku, H.; Suzuki, H.; Okamoto, Y. Copper (II) ions capturing from water using ligand modified a new type mesoporous adsorbent. Chem. Eng. J. 2013, 221, 322-330. [CrossRef]

38. Larkin, P.J. IR and Raman Spectra-Structure Correlations: Characteristics Group Frequencies. In IR and Raman Spectroscopy Principles and Spectral Interpretation; Elsevier: Amsterdam, The Netherlands, 2017; pp. 73-115.

39. Wu, C.-K.; Yin, M.; O’Brien, S.; Koberstein, J.T. Quantitative Analysis of Copper Oxide Nanoparticle Composition and Structure 693 by X-ray Photoelectron Spectroscopy. Chem. Mater. 2006, 18, 6054-6058. [CrossRef]

40. Rahman, M.L.; Fui, C.J.; Tang, X.T.; Sarjadi, M.S.; Arshad, S.E.; Musta, B. Polymer ligands derived from jute fiber for heavy metal removal from electroplating wastewater. Polymers 2020, 12, 2521. [CrossRef] [PubMed] 